Publisher: Taylor \& Francis \& The Canadian Phytopathological Society

Journal: Canadian Journal of Plant Pathology

DOI: $10.1080 / 07060661.2018 .1558284$

Subject category: Review article / Article de synthèse

\title{
Latest advances and future perspectives in Armillaria research
}

\section{RENATE HEINZELMANN ${ }^{1}$, CYRIL DUTECH ${ }^{2}$, TETYANA TSYKUN ${ }^{3}$, FRÉDÉRIC LABBÉ $^{4}$, JEAN-PAUL SOULARUE ${ }^{2}$ AND SIMONE PROSPERO}

${ }^{1}$ Department of Forest and Conservation Sciences, Faculty of Forestry, The University of British Columbia, 2424 Main Mall, Vancouver, BC, V6T 1Z4, Canada

${ }^{2}$ BIOGECO, UMR 1202, INRA, Université Bordeaux, 69 route d'Arcachon, F-33610 Cestas,

France

${ }^{3}$ Swiss Federal Institute for Forest, Snow and Landscape Research WSL, Zürcherstrasse 111, CH-8903 Birmensdorf, Switzerland

${ }^{4}$ Department of Biological Sciences, University of Notre Dame, 100 Galvin Life Science Center, Notre Dame, IN 46556, USA

Correspondence to: R. Heinzelmann. E-mail: renate.heinzelmann@ubc.ca

Accepted 6 December 2018

This document is the accepted manuscript version of the following article:

Heinzelmann, R., Dutech, C., Tsykun, T., Labbé, F., Soularue, J. P., \& Prospero, S. (2019). Latest advances and future perspectives in Armillaria research. Canadian Journal of Plant Pathology. https://doi.org/10.1080/07060661.2018.1558284 
Abstract: The basidiomycete genus Armillaria s.l. (Armillaria s.s. and Desarmillaria) has a worldwide distribution and plays a central role in the dynamics of numerous woody ecosystems, including natural forests, tree plantations for timber production, orchards, vineyards, and gardens. Early studies have shown that all Armillaria species are capable of degrading dead woody substrates causing white rot. Moreover, most species exhibit a parasitic ability, and can be considered as facultative necrotrophs. Although over the years extensive research has been conducted on the phylogeny, biology, and ecology of different Armillaria species, numerous theoretical and applied questions remain open. Recently published studies have provided new perspectives, the most significant of which we present in this review. First, new investigations have highlighted the importance of a multilocus approach for depicting the phylogeny of the genus Armillaria. Second, the importance of clonality and sexuality for the different species is now better described, enabling a more accurate prediction of population dynamics in various environments. Third, genome sequencing has provided new insights into genome evolution and the genetic basis of pathogenicity and wood degradation ability. Fourth, several new studies have pointed out the possible influence of climate change on Armillaria distribution, biology and ecology, raising questions regarding the future evolution of Armillaria species and their effect on ecosystems. In this review, we also give a state-of-the-art overview of the control possibilities of parasitic Armillaria species. Finally, we outline some still open questions in Armillaria research, the investigation of which will strongly benefit from recent methodological advances.

Keywords: fungal forest pathogen, root and butt rot, population dynamics, basidiospores, host, global changes, disease management, -omics 
Résumé: Le genre basidiomycète Armillaria s.l. (Armillaria s.s. et Desarmillaria) a une distribution mondiale et joue un rôle central dans la dynamique de nombreux écosystèmes, notamment en forêts naturelles, dans les plantations forestières, vergers, vignobles, et parcs arborés. Les premières études ont montré que toutes les espèces d'Armillaire étaient capables de dégrader les substrats ligneux morts provoquant une pourriture blanche. La plupart des espèces présentent aussi une capacité parasitaire, et peuvent être considérées comme des nécrotrophes facultatifs. Bien qu'au fil des années, des recherches approfondies aient été menées sur la phylogénie, la biologie, et l'écologie des différentes espèces d'Armillaire, de nombreuses questions théoriques et appliquées demeurent. Des études récemment publiées ont apporté de nouvelles perspectives, dont les plus importantes sont présentées dans cette revue. Premièrement, de nouveaux travaux ont mis en évidence l'importance d'une approche multi-gène pour décrire la phylogénie du genre Armillaria. Deuxièmement, l'importance de la clonalité et de la sexualité des différentes espèces est aujourd'hui mieux estimée, permettant une prédiction plus précise de la dynamique des populations dans divers environnements. Troisièmement, le séquençage du génome a permis de mieux comprendre l'évolution du génome et la base génétique du pouvoir pathogène et de la capacité de dégradation du bois. Quatrièmement, ces études ont mis en évidence la possible influence du changement climatique sur la distribution, la biologie et l'écologie du genre Armillaria, questionnant la future évolution des espèces d'Armillaire et leurs effets sur les écosystèmes. Dans cette revue, nous donnons également un aperçu de l'état de l'art des méthodes de contrôle des espèces d'Armillaire parasites. Enfin, nous identifions plusieurs questions encore ouvertes concernant le genre Armillaria dont la résolution devrait bénéficier fortement des progrès méthodologiques récents. 
Mots clés: agent pathogène des arbres forestiers, pourriture de la souche ou des racines, dynamique des populations, basidiospores, hôte, changements globaux, gestion des maladies, omique. 


\section{General introduction}

The genus Armillaria s.l. (including its closely related genus Desarmillaria; Koch et al. 2017), which currently includes more than 40 officially described species worldwide, plays a central role in the dynamics of numerous woody ecosystems (Shaw III \& Kile 1991). Its high success in terms of species diversity, as well as broad geographical distribution, likely relies on a combination of several factors:

(1) High adaptability to changing environments along geological timeframes. Species radiation in Armillaria s.s. began about 33 million years ago and to date a large number of species with long evolutionary histories exist (Koch et al. 2017). Armillaria species are found from the sea level to high elevations and in different types of soil (Guillaumin et al. 1993). High plasticity to environmental conditions also exists within Armillaria species and may represent an evolutionary advantage for this genus in the face of climate change and adaptation to new hosts (Labbé et al. 2017b);

(2) Armillaria species can acquire new food resources by adopting different strategies. All species exhibit a saprotrophic ability and can exploit all kinds of dead wood (e.g. roots, stumps, debris) from different woody species present in natural and artificial ecosystems (Cruickshank et al. 1997; Prospero et al. 2003a). In this process, both cellulose and lignin are degraded, resulting in a white rot. In this way, Armillaria genets (i.e. mycelium belonging to the same genotype) can persist over several tree generations on the same site and reach estimated ages of more than thousands of years (Ferguson et al. 2003; Bendel et al. 2006a). Some Armillaria species are also polyphagous facultative parasites, able to infect not only a broad range of already weakened (opportunistic or secondary parasites), but also healthy (primary parasites) woody plants (Gregory et al. 1991). Host infection results in a white rot of the roots and root collar which may 
lead to the death of the tree (Fig. 1). Although the ecological strategy is species dependent, it can be influenced by the specific environmental context (Tsykun et al. 2012);

(3) Armillaria species employ an efficient dispersal strategy combining different modes of spread. Local spread (i.e. within a stand) occurs both via rhizomorphs and root contacts. Rhizomorphs are genus-specific (Koch et al. 2017), subterranean, melanized cord-like structures (1-5 mm in diameter), through which Armillaria species occupy the surrounding soil and reach and colonize new food resources (Fig. 1). Preferentially saprotrophic species can develop particularly dense networks of rhizomorphs, both in undisturbed and managed forests (Prospero et al. 2003a; Tsykun et al. 2012). The production of rhizomorphs is considered to be an adaptation strategy to harsh environments that has allowed Armillaria species to acquire a competitive advantage (Koch et al. 2017). In addition to rhizomorphs, direct contact between roots allows the fungal mycelium present in infected roots to infect healthy roots of neighboring trees (Rishbeth 1985; Lung-Escarmant \& Guyon 2004) (Fig. 1). Dispersal over longer distances is assumed to occur via sexual basidiospores, whose role in the Armillaria life cycle is, however, still not completely clear. Effectively, little is known about the substrates on which basidiospores germinate, and at which distance basidiospores may be dispersed (Baumgartner et al. 2011). Recent studies (presented in this review) have evidenced considerable differences among Armillaria species or populations of the same species in the importance of the two ways of dispersal. These differences are most likely related to variations in environmental contexts.

From an anthropocentric point of view, the ecological success of Armillaria species has both positive and negative aspects. As saprotrophs, they are important wood decomposers that contribute to carbon and mineral cycling in forest ecosystems. This seems to be the main role of Armillaria in unmanaged forests (Kim \& Klopfenstein 2011; Tsykun et al. 2012). Here, the selective killing of trees contributes to the replacement of individual trees or even tree species, 
favoring biodiversity and regeneration (Dettman \& van der Kamp 2001a; Bendel et al. 2006b). The parasitic activity of Armillaria is, however, of great concern in artificial and semi-artificial, managed ecosystems, including tree plantations for timber production, orchards, vineyards, parks, and gardens (Baumgartner \& Rizzo 2002; Aguin-Casal et al. 2004; Morrison 2011; Drakulic et al. 2017). Here, tree mortality may lead to severe economic consequences.

Given the dual life style of most Armillaria species, their successful control is still problematic. In particular, removing all possible inoculum sources below ground (e.g. mycelium on residual roots or woody debris) represents a challenging task. Moreover, the broad host range of most parasitic Armillaria species limits the possibilities of selecting less susceptible tree species. Despite several attempts, the use of antagonistic fungi for the biocontrol of Armillaria does not yet represent an effective solution (Baumgartner et al. 2011).

In this review, we aim to highlight the latest research on Armillaria while presenting future perspectives for research. In particular, we show that in order to developing effective management strategies, a holistic approach that better accounts for all three actors (i.e. pathogen, host, and environment) involved in the interaction is necessary. Given recent advances in -omics (particularly genomics, transcriptomics and proteomics) and computational informatics, new conceptual avenues are now possible to better investigate, for example, host-pathogen interactions and population dynamics of Armillaria species. For basic information about the biology and epidemiology of Armillaria, we refer to previous comprehensive publications which are still current (Shaw III \& Kile 1991; Guillaumin et al. 2005; Baumgartner et al. 2011; Guillaumin \& Legrand 2013).

\section{Phylogeny and species diversity}

\section{Species recognition}


Species definition is challenging and over the years several different theoretical and operational species concepts have been developed (Mayden 1997; Taylor et al. 2000). For Armillaria systematics, although three operational species concepts are mainly used (morphological, biological, and phylogenetic species recognition), all have their limitations, and may give conflicting results.

Since Armillaria undergoes sexual reproduction, species recognition based on the morphological characteristics of fruiting bodies (basidiocarps) is reasonable. However, fruiting bodies are rarely available in nature because they are short-lived and irregularly produced over time. Moreover, in some species, fruiting bodies are difficult to induce in vitro and their characteristics do not necessarily resemble those of the fruiting bodies collected in nature (Guillaumin et al. 1985). In addition, the macro- and microcharacteristics of fruiting bodies widely overlap between related species, such as A. cepistipes, A. gallica and A. nabsnona (Antonin et al. 2009; Park et al. 2018) or A. ostoyae and A. gemina (Bérubé \& Dessureault 1989).

Most Armillaria species have a heterothallic mating system (only two haploid mycelia with opposite mating types can fuse) and reproductive barriers exist between species (Guillaumin 2005). Therefore, biological species recognition has been intensively used in the genus Armillaria since the 1970s (Korhonen 1978; Anderson \& Ullrich 1979). Consequently, most of the currently known Armillaria species were first described as biological species. Biological species recognition, however, has some serious limitations. Allopatric species may show incomplete reproductive barriers and be, at least partially, interfertile (e.g. A. cepistipes and $A$. sinapina; Bérubé et al. 1996; Banik \& Burdsall 1998). Moreover, mating tests for species identification in which haploid (single spore) testers of known species are paired with diploid strains of unknown species sometimes provide ambiguous results (e.g. Hasegawa et al. 2011; Keca et al. 2015). Single spore testers for the complete list of Armillaria species are difficult to 
obtain and they may degenerate over time, changing culture morphology independently of the mating process (Harrington et al. 1992).

In recent years, due to rapid progress in DNA-based techniques and the increased availability of DNA sequences, genealogical concordance phylogenetic species recognition, which relies on the concordance of more than one gene genealogy (Taylor et al. 2000), has gained wide popularity. Nevertheless, it also has some constraints for Armillaria systematics. One major drawback is that single gene phylogenies do not necessarily reflect the species" evolutionary history and relationship, eg. because of incomplete lineage sorting, homoplasy, or horizontal gene transfer. As a result, the topology of phylogenetic trees may be incongruent among genes (Kim et al. 2006; Hasegawa et al. 2010; Tsykun et al. 2013; Coetzee et al. 2015; Koch et al. 2017). This issue can largely be avoided by using a multilocus approach (Tsykun et al. 2013; Koch et al. 2017). Intraspecific variation of genes may also be a problem and sometimes blur a species' phylogenetic tree topology, especially if only one gene is considered. For example, A. borealis seems to possess two rather distinct versions of the translation elongation factor $1-\alpha(E F-1 \alpha)$ gene, which appear as unrelated clusters in EF-1 $\alpha$ phylogenies (Tsykun et al. 2013; 2016; Klopfenstein et al. 2017). However, in multilocus phylogenies, A. borealis is usually represented as a single cluster (Tsykun et al. 2013; Guo et al. 2016). Reconstructing species phylogenies with a multitude of genes or even genomic data would be required to circumvent the biases of single gene phylogenies and to further unravel the mechanisms behind speciation in this large genus.

Species delimitation based on the phylogenetic approach should also be biologically meaningful and criteria have to be developed to distinguish between intraspecific genetic lineages, representing intraspecific variation, and new taxonomic entities, representing new species. A polyphasic approach should be followed to equate genetic lineages with biological (reproductive), morphological, and functional differentiation. Recent studies by Brazee et al. 
(2012b), Hood \& Ramsfield (2016) and Elías-Román et al. (2018) which describe three new species (A. altimontana, A. aotearoa and A. mexicana, respectively) represent good examples of a successful co-application of different species recognition approaches. For example, $A$. altimontana was for a long-time recognized as a distinct biological species in North America (NABS X) (Anderson \& Ullrich 1979; Morrison et al. 1985; Banik \& Burdsall 1998). Later on, its species rank was confirmed using different molecular techniques (Kim et al. 2000; Kim et al. 2001; Ross-Davis et al. 2012). Consequently, A. altimontana was recently formally described as a new species, including its morphological characteristics (Brazee et al. 2012b). Furthermore, $A$. altimontana appears to be specifically associated with Abies-dominated forest types at mesic, higher elevation sites of the western interior of North America (Brazee et al. 2012b). A similar case is represented by $A$. aotearoa in New Zealand (Hood \& Ramsfield 2016). In contrast, $A$. mexicana was discovered as a distinct phylogenetic species in Mexico (Elías-Román et al. 2013). Extensive analysis of its morphological features confirmed its separation from other North American species (Elías-Román et al. 2018).

An interesting case where biological species recognition is questioned by phylogenetic species recognition is A. ostoyae. This species is widespread in the Northern Hemisphere and isolates from Eurasia and North America show interfertility (Anderson et al. 1980). However, recent phylogenetic analyses suggest that North American A. ostoyae and Eurasian A. ostoyae represent closely related, but clearly distinct genetic lineages (Klopfenstein et al. 2017), raising the question of whether these lineages are actually different (sub)species. Although for now the official name of the species, including both lineages, is still A. ostoyae (on July 292017 , the recommendation of the Nomenclature Committee for Fungi to conserve $A$. ostoyae over $A$. solidipes (May 2017), was accepted by the International Botanical Congress (Turland et al. 
2017)), further taxonomic and phylogenetic investigations, including multiple genes or genomic data, would be necessary to clarify this question.

\section{Phylogeny}

Since the 1990s, the phylogeny of the genus Armillaria has been explored based on molecular variations in different genes. Initially, mainly the tandemly repeated multicopy ribosomal DNA (rDNA) operons (Duchesne \& Anderson 1990; Anderson \& Stasovski 1992), in particular the intergenic spacer 1 (IGS-1) between the $28 \mathrm{~S}$ and $5 \mathrm{~S}$ gene and the internal transcribed spacers (ITSs) between 18S and 5.8S and 5.8S and 28S, were studied (Harrington \& Wingfield 1995; Kim et al. 2000; Coetzee et al. 2003; Kim et al. 2006). Subsequently, Maphosa et al. (2006) demonstrated the utility of the single copy EF-1 $\alpha$ gene for constructing phylogenies in Armillaria. In comparison to rDNA sequences, the EF-1 $\alpha$ gene appears to better resolve closely related Armillaria species, such as A. gallica and A. cepistipes and other related species (Maphosa et al. 2006; Hasegawa et al. 2010; Ross-Davis et al. 2012; Tsykun et al. 2013; Coetzee et al. 2015; Guo et al. 2016; Klopfenstein et al. 2017). Hence, this gene represents a valuable diagnostic tool for the genus.

Multilocus phylogenies have recently begun to replace single gene phylogenies (Tsykun et al. 2013; Guo et al. 2016; Koch et al. 2017), as they describe the evolutionary history of the genus more accurately. The reconstruction of the phylogeny of the genus based on genomic data is currently possible only for very few species (Sipos et al. 2017) because of the limited number of available genomes.

The phylogenetic studies conducted in recent years consistently attribute the genus Armillaria to the Agaricales superclade within the Basidiomycota, where it forms, together with other genera, the family Physalacriaceae (Matheny et al. 2006; Collins et al. 2013). A recent 
phylogenomic analysis, based on 835 conserved single copy genes, confirmed the phylogenetic position of the genus Armillaria in this family, and identified Guyanagaster and Cylindrobasidium as the most closely related sister genera (Sipos et al. 2017). In agreement with each other, the studies by Koch et al. (2017) and Sipos et al. (2017) date the split of Armillaria from its sister genus Guyanagaster to 40-50 million years ago. Since recently, two separate genera are recognized within Armillaria, the genus Desarmillaria, composed of the ex-annulated species D. ectypa and D. tabescens (formerly A. ectypa and A. tabescens), and the genus Armillaria s. s., which contains all species characterized by annulated fruiting bodies (Koch et al. 2017).

The Northern and Southern Hemisphere harbor distinct sets of Armillaria species (Fig. 3) which constitute clearly separated clades in the phylogeny of Armillaria (Klopfenstein et al. 2017; Koch et al. 2017), thereby confirming previous studies with similar findings based on analyses of fewer isolates (Coetzee et al. 2011). The few Armillaria species that the Southern Hemisphere shares with the Northern Hemisphere (Fig. 3) were most likely introduced accidentally by humans through the transport of infected plant material (e.g. A. mellea was introduced to South Africa from Europe by early Dutch settlers, Coetzee et al. 2001b; Coetzee et al. 2018).

To date, phylogenetic analyses of Northern Hemisphere species including various DNA regions (e.g. translation elongation factor 1- $\alpha$ gene, ribosomal IGS-1 and ITS regions) have generally been consistent in depicting the following superclades: (1) "Desarmillaria" clade including D. ectypa and D. tabescens; (2) "Ostoyae" clade including A. ostoyae, A. borealis and A. gemina; (3) "Gallica" clade including A. gallica, A. calvescens, A. cepistipes, A. altimontana, A. sinapina, A. nabsnona; and the undescribed biological species Nag. E from Japan, and (4) “Mellea" clade including A. mellea, A. mellea ssp. nipponica and A. mexicana (Hasegawa et al. 
2010; Tsykun et al. 2013; Coetzee et al. 2015; Guo et al. 2016; Klopfenstein et al. 2017; Koch et al. 2017). Phylogenetic studies of Armillaria species from the Southern Hemisphere have thus far outlined the existence of: (1) “Australasian-South American” superclade containing A. novaezelandiae, A. affinis, A. limonea, A. paulensis, A. hinnulea, A. pallidula, A. fumosa, and $A$. luteobubalina, and (2) “African superclade" containing A. camerunensis, A. heimii and A. fuscipes (Coetzee et al. 2001a; Coetzee et al. 2003; Coetzee et al. 2005a; Coetzee et al. 2005b; Maphosa et al. 2006; Lima et al. 2008; Pildain et al. 2009; Koch et al. 2017).

Besides these well-known and well-characterized Armillaria species and subspecies, numerous new phylogenetic lineages have been discovered in recent years (e.g. Coetzee et al. 2005b; Guo et al. 2016) whose taxonomic rank is sometimes still not clear.

\section{Biogeography}

The first study on the biogeography of Armillaria by Kile et al. (1994), which was based on species distribution patterns, suggested that ancestral forms of Armillaria already existed before continents started to separate and that the present-day distribution of the genus resulted from adaptive radiation mediated by the break-up of these landmasses. More recent studies, however, relying upon molecular clock analyses, have estimated the genus to be much younger, rejecting the previous hypothesis (Coetzee et al. 2011; Koch et al. 2017). According to Koch et al. (2017), the armillarioid clade, which currently includes the genera Armillaria s.s., Desarmillaria and Guyanagaster, arose approximately 51 million years ago in Eurasia, which is well after continental break-up. Armillaria s.s. separated from Desarmillaria approximately 41 million years ago, and started to diversify approximately 33 million years ago. The ancestral range analyses conducted by Koch et al. (2017) suggest that Armillaria migrated from Eurasia to Africa and Australasia, and was introduced multiple times from Eurasia to North America. The authors 
propose that Armillaria migrated as a pathogen of existing plants at that time, and that species started to diverge after available pathways disappeared and migration was no longer possible. Interestingly, the predicted origin of Armillaria in South America is Australasia and not North America. Koch et al. (2017) hypothesize that Armillaria may have travelled from Australasia to South America along an ancient dispersal route via the Antarctic, or alternatively by longdistance dispersals of basidiospores.

\section{Species diversity and distribution}

Even though the Index Fungorum (http://www.indexfungorum.org/) and Mycobank (http://www.mycobank.org/) currently list about 70 Armillaria species, only approximately 40 of them are well-characterized (Fig. 3). The other taxa mainly represent morphological species which were described in the early days of Armillaria research but were never equated with biological or phylogenetic species. Although, to date, we have a general overview of the global distribution of the different Armillaria species (Fig. 3), most publications on the topic involve isolates from Europe and North America, whereas collections from Asia, South America, and Africa are still relatively sparse. Moreover, detailed knowledge of the regional incidence and ecology of many of the reported species is frequently lacking, as most reports are limited to host and host status (dead or alive).

\section{Sympatric species interaction}

Field investigations conducted mainly in North America and Europe have shown that several Armillaria species can occur sympatrically in the same forest stand (e.g. Legrand et al. 1996; Cruickshank et al. 1997; Bruhn et al. 2000; Dettman \& van der Kamp 2001a; Prospero et al. 2003b; Bendel et al. 2006a; Szewczyk et al. 2016; Mesanza et al. 2017). The co-occurrence of 
preferentially saprotrophic and parasitic species appears to be particularly frequent, as in the case with A. cepistipes or A. sinapina with A. ostoyae and A. mellea with A. gallica. This may reflect evolution of different ecological strategies because of competition for the same resources.

Since the mentioned studies only provide a "snapshot" for the evolution of Armillaria species, repeated sampling and analyses over time in the same stand, combined with experimental studies, would provide more information on the outcome of interspecific interactions, such as the long-term co-existence of different species or replacement of one species by another. For instance, a study conducted by Prospero et al. (2006) involving potted Norway spruce (Picea abies) seedlings suggested a rather neutralistic co-existence of A. cepistipes and A. ostoyae as rhizomorphs in the soil. Regarding their ability to colonize stumps, however, the two species appeared to experience a mutually negative effect from the interaction, likely because of interspecific competition.

\section{Population structure and dynamics}

\section{Vegetative spread}

One important biological trait of Armillaria species is their ability to spread in the soil via rhizomorphs (Rishbeth 1988; Guillaumin et al. 1993; Prospero et al. 2003a; Tsykun et al. 2012). This form of vegetative propagation combined with mycelial transfer from root to root can under certain circumstances result in the formation of very large clonal individuals (Smith et al. 1992; Ferguson et al. 2003; Bendel et al. 2006a). More often, however, the estimated size of an Armillaria genet measures less than one hectare (Brazee et al. 2012a; Travadon et al. 2012; Dutech et al. 2017; Lehtijarvi et al. 2017; Tsykun et al. 2017).

The observed variation in genet size is partly due to differences among Armillaria species in their ecological strategies. Some species (e.g. A. gallica, A. cepistipes) intensively produce 
perennial rhizomorphs through which they rapidly expand in the soil and capture new food resources (Guillaumin et al. 1993; Prospero et al. 2006). For instance, Tsykun et al. (2012) estimated that the rich organic soils of Ukrainian primeval beech (Fagus sylvatica) forests harbor approximately $512 \mathrm{~kg}$ of rhizomorphs (dry weight) per hectare, mainly by A. cepistipes. For other species (e.g. A. mellea, A. ostoyae), rhizomorphs are less abundant and spread in the soil mainly occurs via root contact (Baumgartner \& Rizzo 2001).

\section{Intraspecific genet size differences}

Important differences in genet size have also been observed among populations of the same species, such as in A. ostoyae (Dettman \& van der Kamp 2001b; Ferguson et al. 2003). Several authors have assumed that these intraspecific differences might be related to the frequency and intensity at which sexual reproduction occurs in the specific population (Ferguson et al. 2003; Bendel et al. 2006a). Humid and mild climatic conditions are assumed to favor fructification and consequently the production of sexual basidiospores (Ferguson et al. 2003). This could lead to higher rates of establishment for new genotypes of Armillaria spp. and to stronger competition for host resources among genotypes, which may result in more numerous, discrete and small genets. Other factors such as composition, distribution and density of tree species, soil properties (e.g. the amount of organic material in the litter, temperature, water saturation), or anthropogenic disturbances (e.g. logging, stump removal) may also affect the density and size of Armillaria genets (Guillaumin \& Legrand 2005; Szewczyk et al. 2016; Kubiak et al. 2017).

An elegant method for comparing the spatial genetic structure of Armillaria populations would be the molecular characterization of the clonal structure by conducting random sampling over several tens of hectares and estimating the mean clonal range for each population. This would determine the minimum distance at which clonality has no further effect on population 
genetic structure as performed in Reusch et al. (1999). Such estimates have recently been obtained for an A. mellea population in California, USA (Travadon et al. 2012) and an A. ostoyae population in France (Dutech et al. 2017). Both studies reported small mean clonal ranges (130 m and $<150 \mathrm{~m}$, respectively). This is consistent with small genet sizes expected in geographical areas that have warm climates and humid winters, thus stimulating fructification.

\section{Spread by basidiospores}

The importance of basidiospores for population dynamics of Armillaria species has been debated for a considerable time, mostly because, for the majority of species, the substrate on which basidiospores germinate is still not clearly identified (Baumgartner et al. 2011). Although some studies report evidence of successful germination on fresh dead wood (stumps and buried wood segments; e.g. Hood et al. 2008), artificial inoculations of the same types of substrates have failed or obtained very low success rates (Rishbeth 1970; Kile 1983). These results specifically question the importance and frequency of the establishment of new genotypes in natural populations via basidiospores and generally highlight the difficulty of Armillaria inoculations.

The frequent occurrence of a large number of small genets in newly planted forests suggests that germination of basidiospores may be efficient under some specific environmental conditions (Rishbeth 1970, 1988; Legrand et al. 1996). Recent population genetic studies have confirmed that local populations (i.e. at the scale of tens or hundreds of hectares) are generally composed of numerous genets with low or no linkage disequilibrium between alleles (after removing the clonal effect), suggesting that sexual reproduction is a major evolutionary process in Armillaria populations (Travadon et al. 2012; Dutech et al. 2017). Using spatial genetic structure analysis and isolation-by-distance models (Wright 1969; Rousset 1997), these studies have also estimated that spatial dispersal of basidiospores occurs mainly within a few hundred meters (Travadon et al. 
2012; Dutech et al. 2017), which is consistent with previous direct estimates of spore dispersal (Worrall et al. 2004; Power et al. 2008). This limited dispersal of most basidiospores could explain the significant inbreeding rate estimated within several populations (Prospero et al. 2008; Baumgartner et al. 2011; Tsykun et al. 2017). These results should, however, be confirmed by additional studies as they appear to be influenced by the type of molecular markers considered, having been mainly obtained by means of microsatellite markers (Labbé et al. 2017a; Tsykun et al. 2017) which in the presence of null alleles may create a spurious signal of inbreeding (Chybicki \& Burczyk 2009). The relatedness among genotypes could for example be verified using single nucleotide polymorphisms (SNPs) or markers targeting mating type alleles.

Despite the progress made in population genetic analyses, questions remain regarding the timing and conditions required in nature for the germination and fusion of sexually compatible basidiospores to produce a new diploid mycelium. Recently, Heinzelmann et al. (2018) suggested that basidiospores may be present in nature at high density. This would enable the rapid diploidization of a haploid mycelium, leading to successful colonization of an organic substratum and subsequent infection of a new host. The establishment of numerous new diploid genotypes could, therefore, occur over short time periods, when local environmental conditions are favorable (Legrand et al. 1996), and assuming that many spores with compatible (different) mating-type alleles are germinating on the same substrate at the same time.

Another mycelial fusion frequently assumed to be important in the population dynamics of Armillaria species is the so-called Buller phenomenon (Korhonen 1978). It is well described for in vitro pairings of haploid and diploid mycelium, and was widely used for biological species identification (e.g. Rizzo \& May 1994) before molecular tools started to gain importance. However, the Buller phenomenon has not yet been observed in nature. Moreover, it should have a limited effect on the genetic population structure, since, at least in vitro, it generally results in the 
replacement of the haploid nucleus by the diploid nucleus with very rare recombination events among nuclei (Rizzo \& May 1994; Carvalho et al. 1995). A recent genomic study performed on a large genet of A. gallica (Anderson \& Catona 2014) did not detect such recombination events, confirming their rarity in natural populations.

\section{Estimation of gene flow}

The estimation of the restricted dispersal of most basidiospores within a few hundred meters seems to contradict several studies performed at larger spatial scales (i.e. the order of hundreds to thousands of hectares) at which estimates of genetic differentiation among populations were low or not significantly different from zero (Prospero et al. 2008; Baumgartner et al. 2010c; Brazee et al. 2012a; Heinzelmann et al. 2012; Tsykun et al.2017). The rare long-distance spore dispersal events described in other fungal species (Edman et al. 2004) may also occur in Armillaria and mitigate spatial genetic structure at large spatial scales.

Inconsistent results among population genetic studies performed at different spatial scales are, indeed, not uncommon (e.g. Puebla et al. 2012 for marine organisms), and not necessarily associated with significant gene flow among populations. Quantification of current gene flow using genetic differentiation estimates is problematic because such estimates depend on theoretical models with assumptions that are often biologically unrealistic (Whitlock \& McCauley 1999). Moreover, when an isolation-by-distance model is assumed and the spatial scale of the study is not in accordance with the dispersal range of the species, gene flow estimates may become unlinked to the estimated genetic differentiation among populations (Rousset 1997). All these factors may explain why only a weak signal of genetic differentiation was detected at the landscape scale in Switzerland in A. cepistipes (Heinzelmann et al. 2012), or in Eastern North 
America in A. gallica (Brazee et al. 2012a), despite the estimation of the restricted dispersal of most basidiospores at the local scale (Travadon et al. 2012; Dutech et al. 2017).

\section{Historical effects on genetic diversity}

In contrast to studies that have shown low $F_{S T}$ estimates, Bayesian genetic analysis and principal component analysis have demonstrated the existence of several differentiated genetic clusters for A. mellea in North America (Baumgartner et al. 2010c), A. cepistipes in Europe (Tsykun et al. 2017), and A. luteo-virens in Asia (Xing et al. 2014). As for their host tree populations in the Northern Hemisphere (Hewitt 2000), past climatic changes associated with periods of glaciation may have affected the geographical distribution of most Armillaria species, leading to genetic isolation between surviving populations in different geographical refuges. It is noteworthy that different genetic clusters appear to co-exist in the same geographical region (e.g. Eastern North America) suggesting that recolonization originated from different genetically divergent refuges (Baumgartner et al. 2010c). The historical signal of recolonization is strong in A. mellea in North America, and has been confirmed by phylogenetic studies (Baumgartner et al. 2012). In contrast, no such signal was detected in any Armillaria species in Europe (Tsykun et al. 2013), indicating the minor effect of past glaciation on the genetic diversity of Armillaria species within this continent. However, this absence of a phylogeographical signal could also be due to insufficient sample sizes in continental studies. Approximate Bayesian computation analyses of an A. ostoyae population in France found the signature of a genetic bottleneck that may have occurred more than 10,000 years ago, which would correspond with the end of the last glacial period (Labbé et al. 2017a). These contrasting results suggest that the impact of past climatic changes is rather different among Armillaria species and geographical regions. Additional phylogeographical studies, combining new statistical and genomic methods (e.g. Boitard et al. 2016) with more 
intense sampling over continental areas, should be performed to better understand the evolutionary history of Armillaria species.

\section{Methodological advances}

Since the advent of molecular biology, both the number and type of markers available for population genetic analyses have rapidly increased. This also holds true for non-model organisms such as Armillaria species. Some authors have pointed out that the nature of molecular markers itself may also affect the outcome of population genetic studies, in addition to the sampling strategy adopted. For instance, microsatellite (single sequence repeats, SSR) and single nucleotide polymorphism (SNP) markers have different rates and mechanisms of mutation, genome-wide distribution patterns, and biological functions (Guichoux et al. 2011; Fischer et al. 2017). In a recent study by Tsykun et al. (2017), these two types of markers showed contrasting sensitivity when used for depicting the population structure of $A$. cepistipes at different spatial scales. SSRs were best suited to detect genetic structure at a smaller geographic scale under a systematic sampling in interconnected forests. In contrast, SNPs in conserved single copy genes were less sensitive to sampling design and revealed ancient divergence between distant populations. Therefore, the molecular markers to be used should be carefully selected based on the specific goals of the particular study.

\section{Genomics and beyond}

\section{Genomes}

The start of genomics in Armillaria was marked with the release of the A. mellea genome in 2013 (Collins et al. 2013). More recently, Sipos et al. (2017) sequenced, assembled, and analyzed four other Armillaria genomes, including those of $A$. cepistipes, A. gallica, as well as those of a 
European and a North American A. ostoyae strain. In addition, the draft genome sequence of $A$. fuscipes, the first Armillaria species from the Southern Hemisphere to be sequenced, is also available (Wingfield et al. 2016). The genomes of $A$. mellea and A. fuscipes are still highly fragmented, whereas the genomes of the other species are assembled to a high degree (Table 1). To date, however, none of these genomes have been assembled to chromosome-scale sequences.

In contrast to most other white rot fungi, Armillaria species have large genomes ranging from 53 to $85 \mathrm{Mb}$, and are predicted to contain 14,473 to 25,704 genes (Collins et al. 2013; Wingfield et al. 2016; Sipos et al. 2017; Table 1). Pairwise comparisons of the genomes of different Armillaria species have revealed a high degree of synteny (Sipos et al. 2017). Moreover, the comparison of five of these Armillaria genomes with the genomes of 22 other Agaricomycetes has revealed a significant genome expansion in the genus Armillaria (Sipos et al. 2017). Interestingly, this expansion is driven by gene family diversification, and not by transposon proliferation as observed for other plant pathogenic fungi (Raffaele \& Kamoun 2012). The expanded gene families include pathogenicity-related genes, genes involved in lignocellulose-degradation, and Armillaria-specific genes with mostly unknown functions, several of which are important for rhizomorph development (Sipos et al. 2017). The expansion of transposable elements in Armillaria genomes is only modest compared with other members of the Agaricomycetes. In addition, it appears that weakly pathogenic species, such as $A$. cepistipes and A. gallica, tend to have a greater number of repetitive sequences (i.e. transposons) than more pathogenic species, such as $A$. ostoyae and $A$. mellea (Sipos et al. 2017).

\section{Wood degrading genes}

The versatility of Armillaria species as white-rot fungi to degrade all structural components of plant cell walls is well reflected in their genomes which possess a large repertoire of genes 
associated with plant cell wall degradation, including lignin-, cellulose-, hemicellulose- and pectin-degrading enzymes (Collins et al. 2013; Sipos et al. 2017). In contrast with other white-rot fungi, the genomes of Armillaria species (albeit those examined to date) show an underrepresentation of ligninolytic gene families and an overrepresentation of pectinolytic gene families (Sipos et al. 2017). The in vivo activity of some plant cell wall degrading genes has been confirmed by the transcriptomic analysis of a mycelial fan invading a grand fir (Abies grandis) sapling (Ross-Davis et al. 2013), and the proteomic and transcriptomic analysis of different tissues and developmental stages of in vitro cultures (Collins et al. 2013; Sipos et al. 2017). The secretion, presence, and activity of a very limited number of ligninolytic enzymes in infected host tissue had been previously demonstrated (Robene-Soustrade et al. 1998; Stoytchev \& Nerud 2000).

The rich machinery of the plant cell wall degrading enzymes of Armillaria likely also aids pathogenicity by, for example allowing Armillaria early access to dead wood, thereby potentially bypassing competing microbes as suggested by Sipos et al. (2017).

\section{Pathogenicity-related genes}

The genomes of Armillaria encode a range of genes more specifically associated with pathogenicity (Sipos et al. 2017). Some examples include expansins, which help loosen plant cell walls, cerato-platanin genes, which induce cell death in the host, salicylate hydroxylases, which may help to develop tolerance against salicylic acid that plays an important role in plant defense, or LysM (CBM50) domains. The latter are particularly overrepresented in Armillaria (Sipos et al. 2017), and may play a role in the suppression of chitin-triggered host immunity and the protection of the fungal cell wall from hydrolysis through chitinases and other hydrolytic enzymes secreted by the host or competing microbes (Kombrink \& Thomma 2013; Akcapinar et 
al. 2015; Sánchez-Vallet et al. 2015). Further, Armillaria encodes many pathogenicity associated secondary metabolites (e.g. terpene cyclases, nonribosomal peptide synthetases-like, prenyl transferases, halogenases, and polyprenyl synthases), small secreted proteins, as well as other genes that may assist in pathogenicity, such as genes involved in competitive abilities against microbes (e.g. Cys-2 peroxiredoxin, thioredoxin, class II chitinase, prohibitins, and many other redox-active, degradative and attack-type proteins) (Collins et al. 2013; Sipos et al. 2017).

\section{Secondary metabolites}

Secondary metabolites, often also called natural products, are small molecules produced by fungi and other organisms which do not have an essential function in normal growth and development. The genomes of Armillaria species encode several genes involved in the biosynthesis of secondary metabolites (Sipos et al. 2017). Among other functions, secondary metabolites are associated with pathogenicity and competition with other microbes. Misiek \& Hoffmeister (2012) demonstrated the inhibitory effect of sesquiterpene aryl esters, the main group of secondary metabolites produced by Armillaria, against other wood-degrading Basidiomycetes. In line with this, a wide array of genes involved in secondary metabolism is expressed in rhizomorphs (Sipos et al. 2017). In addition, the cytotoxicity of secondary metabolites of Armillaria against human cancer and non-cancer cells has been demonstrated (Misiek et al. 2009; Bohnert et al. 2011; Bohnert et al. 2014b). To date, however, the mechanisms behind these antifungal and cytotoxic properties of secondary metabolites in Armillaria are barely understood (Bohnert et al. 2014a; Bohnert et al. 2014b). Interestingly, the two properties appear to be unlinked and follow a dissimilar structure-activity relationship (Bohnert et al. 2014a).

\section{Validation of gene functions}


The functional validation of genes in Armillaria is still lacking, and new genetic tools need to be developed to attain this goal. To date, the only established tools are a transformation system that makes use of Agrobacterium tumefaciens and permits the transformation of basidiospores and a system for heterologous gene expression (Baumgartner et al. 2010b; Ford et al. 2015, 2016). Currently, efforts are underway to establish CRISPR-Cas9 technology for gene editing in Armillaria (Ford \& Bourquin 2018), which, once operational, may facilitate the study of gene function in Armillaria considerably.

\section{Genetic mapping}

In contrast to a genome sequence, which is a physical representation of the genome and gives the absolute positions of loci on a chromosome, a genetic map shows the relative positions of loci along a chromosome, with the distance between loci being proportional to the observed recombination rate between them. Recently, Heinzelmann et al. (2017a) published the first highdensity genetic map for an Armillaria species, namely A. ostoyae, which contains 11 linkage groups and has a total length of $1,007.5 \mathrm{cM}$. This map anchors 61 of the 109 scaffolds $\approx \approx 3 \%$ of the total sequence length) of the A. ostoyae genome assembly published by Sipos et al. (2017) and shows a high collinearity with that genome, indicating the accuracy of both, the genome assembly and the linkage map for A. ostoyae.

A genetic map also enables the study of the genetic basis of variation in morphological characteristics. For example, conspecific Armillaria strains may substantially differ in their phenotypic characteristics such as virulence, rhizomorph production, and growth rate (Prospero et al. 2004; Heinzelmann \& Rigling 2016; Heinzelmann et al. 2017b; Labbé et al. 2017b). A quantitative trait locus (QTL) analysis conducted by Heinzelmann et al. (2017a) identified a single, gene dense region of $87 \mathrm{~kb}$ linked to a severe defect in hyphal growth in $A$. ostoyae, which 
segregated as a natural mutation in the mapping population. Although further analyses are needed to determine which candidate gene is the cause of the dramatically altered growth phenotype, the successful application of forward genetics in Armillaria highlights that genetic mapping combined with high-quality genomic data can be used to elucidate the genetic basis underlying natural variation in phenotypic traits.

\section{Impact of climatic and environmental changes}

\section{General considerations}

Climate change, invasive species and changes in forest management not only have an impact on forest ecosystems, but also on the pathogens inhabiting them (Desprez-Loustau et al. 2016). However, how climatic and environmental changes are affecting Armillaria, its hosts, and their co-existence is poorly understood, and research over the last few years on the pathogen side has not brought many new insights (see the recent review of Kubiak et al. 2017). Predicting the effect of climate change on the incidence of Armillaria root disease, for example, is challenging because different stages of lifecycle, including dispersal, infection, and reproduction, may be affected directly and indirectly, and effects may be completely different (La Porta et al. 2008; Dukes et al. 2009; Kubiak et al. 2017). In addition, the lack of long-term studies on tree mortality associated with Armillaria and its multiple and complex interactions with environmental changes induced by human activities (Cienciala et al. 2017) limit our understanding of the evolution of Armillaria in a changing environment.

\section{Species distribution}

Climate change is generally expected to cause shifts in the geographic distribution of species, including Armillaria and its hosts (Klopfenstein et al. 2009; Hanewinkel et al. 2012; Dyderski et 
al. 2018). Such shifts are expected to be more pronounced at the species' Northern and Southern distribution range margins, and could strongly affect the dynamics of ecosystems by changing the composition of the resident Armillaria community. Because interactions between Armillaria species, as well as the climatic niches occupied by different species, are still poorly characterized (Cruickshank et al. 1997; Prospero et al. 2006), it is difficult to accurately predict the outcome of the geographical shifts. In theory, different Armillaria species could co-exist and occupy different ecological niches, or some species could be replaced by others.

A promising way to investigate these questions is illustrated in the study of Klopfenstein et al. (2009). The authors modeled the current and prospective distribution of $A$. ostoyae in western North America along with that of Douglas-fir (Pseudotsuga menziesii), a frequent host species in this region, using bioclimatic models. The predicted shifts in suitable climate space for A. ostoyae were minor, whereas the suitable climate space of Douglas-fir was markedly reduced, suggesting that Armillaria may cope better with a changing climate than its host species.

\section{Armillaria survival and incidence}

Even though the geographic distribution of Armillaria species may not change significantly within the next few decades, higher annual temperatures may directly affect the activity of the fungus. For example, in regions with temperate climate, warmer winters may lead to an extension of the activity period of rhizomorphs (Rishbeth 1978). In addition, higher precipitation and temperatures in autumn may favor Armillaria fructification, especially in Boreal regions, thereby increasing the importance of dispersal by basidiospores as suggested by Ferguson et al. (2003). In contrast, higher summer temperatures, predicted by different climatic scenarios, may lead locally to overheated and dry soils, whose impact on survival and growth of Armillaria inoculum and rhizomorphs is uncertain. The few studies that have investigated the effects of soil moisture on 
rhizomorph growth have found evidence of the negative impact of drought on some Armillaria species (e.g. A. luteobubalina; Pearce \& Malajczuk 1990).

Another aspect which has been partially neglected, is the survival of Armillaria in wood during the dry season and times of drought. Although several studies have investigated the importance of soil depth, tree species, or the size of wood fragments for Armillaria conservation (e.g. Bruhn et al. 1998; Kromroy et al. 2005), to our knowledge, no exhaustive data is available on the effects of drought on this possibility of survival. Armillaria species typically produce a pseudosclerotial plate (visible as dark zone lines) around the colonized wood, which is thought to protect the mycelium against antagonistic interactions with other microbes (Guillaumin \& Botton 2005). This structure, comparable to the melanized outer cortex of rhizomorphs, could also help in case of unfavorable abiotic conditions in uncolonized sections of the neighboring substrate. Thus far, these presumed seasonal and interactive effects of climate change, together with the quality of wood resources, and soil properties have only been studied with respect to a few Armillaria species.

\section{Host predisposition}

Armillaria will be indirectly affected by climatic and environmental changes through the predisposition of its hosts to disease because of chronic stress due to climatic maladaptation (Desprez-Loustau et al. 2006; Dukes et al. 2009; Sturrock 2012; Dempster 2017). Furthermore, tree susceptibility to disease agents will be temporarily increased by more frequent extreme weather events such as droughts, storms, temperature extremes, and floods (Woods et al. 2010; Seneviratne et al. 2012). Armillaria may specifically benefit in regions where mild and humid seasons (promoting growth and dispersal of the pathogen) alternate with dry and hot seasons, increasing host stress and allowing the pathogen to overcome the host's defenses. Some extreme 
events, such as periodic floods, besides increasing host stress and susceptibility, may also reduce inoculum potential by reducing rhizomorph abundance in the soil (Szewczyk et al. 2016).

Climatic stressors often interact with biotic stressors, such as foliar and other pathogens or pests, leading to complex tree decline syndromes. Armillaria is regularly reported to be involved in such declines occurring after droughts and/or severe outbreaks of foliar pathogens (Wargo \& Harrington 1991; Clinton et al. 1993; Burrill et al. 1999; Horsley et al. 2002; Marçais \& Breda 2006; Haavik et al. 2015; Pavlov 2015; Holuša et al. 2018). The specific role of Armillaria in such declines has, however, rarely been assessed in the past and is often difficult to disentangle from the effects of other contributing agents.

Recently, Aslam \& Magel (2018) demonstrated that drought-stressed saplings of black locust (Robinia pseudoacacia) that were wound-inoculated with $A$. mellea during dormancy were unable to restrict the spread of the pathogen. In contrast, drought stressed black locust saplings that were wound-inoculated during the growing season were able to prevent the establishment of A. mellea, as observed in the well-watered saplings. This suggests that not only abiotic stress may have an effect on host susceptibility to Armillaria, but also the time of year when such stress occurs.

Some time ago, Wargo $(1972,1996)$ hypothesized that specifically the depletion of starch reserves and the excess of available glucose, fructose and nitrogen in the bark and outerwood of roots, in response to drought stress or defoliation may promote the growth of Armillaria and reduce host ability to compartmentalize Armillaria infections. Interestingly, screening for resistance against Armillaria root disease in Douglas-fir reveals that trees with greater levels of Armillaria resistance also have a higher drought tolerance (Cruickshank \& Filipescu 2017), suggesting that more frequent drought associated with climate warming, over the long-term, may select for trees with higher resistance to Armillaria infection. 
Interactions with exotic pathogens

Non-native fungal pathogens that are accidentally introduced into a new area can be drivers of ecological change (e.g. Loo 2009). They may, in turn, interact in the new environment with native pathogens, such as Armillaria species, thereby exacerbating tree decline. In Europe, native Armillaria species have been shown to interact with the invasive pathogen Hymenoscyphus fraxineus, the causal agent of ash dieback (Gross et al. 2014). This fungus may cause, among other symptoms, necrotic collar lesions at the stem base of European ash (Fraxinus excelsior) and narrow-leafed ash (Fraxinus angustifolia) (Husson et al. 2012; Chandelier et al. 2016). Such lesions may be secondarily invaded by Armillaria species, which may reduce tree stability and accelerate tree decline (Lenz et al. 2016; Marçais et al. 2016; Enderle et al. 2017; Timmermann et al. 2017). Remarkably, A. gallica and A. cepistipes usually prevail in the collar necrosis, suggesting that less pathogenic and preferentially saprotrophic Armillaria species actually benefit from the interaction with H. fraxineus (Skovsgaard et al. 2010; Bakys et al. 2011; Husson et al. 2012; Marçais et al. 2016; Enderle et al. 2017).

\section{Control of Armillaria root disease}

\section{General considerations}

The control of Armillaria root disease in forest and agricultural systems is challenging because of the saprophytic ability of Armillaria and its hidden growth below ground (Redfern \& Filip 1991; Guillaumin et al. 1993). The potential of Armillaria to persist for decades in dead wood (e.g. stumps, woody debris or root fragments in the soil) results in an increased risk of tree mortality in subsequent tree plantations on infected sites (e.g. Lung-Escarmant \& Guyon 2004; Kromroy et al. 2005). The choice of disease management strategies strongly depends on the targeted ecosystems 
and the economic value of the host species (Bogdanski et al. 2018). Until now, control strategies for Armillaria root disease have primarily been aimed at reducing the amount of Armillaria inoculum in the soil, either by removing infected plants and woody debris after tree harvesting or by treating the soil of infected stands with highly toxic fumigants (Baumgartner et al. 2011). In recent years, due to the worldwide ban of the fumigant methyl bromide, fumigant research has generally stopped and more environmentally-friendly control methods, such as post-infection treatments, the mitigation of yield losses, or the planting of less susceptible or resistant hosts, have been proposed as possible alternatives (Baumgartner et al. 2011). The development of new biological control methods and the improved characterization of microbiological soil communities (Vayssier-Taussat et al. 2014) will provide new promising options to control Armillaria root disease.

\section{Mechanical stump removal}

The practice of mechanically removing stumps and as much of the root system as possible after logging (to reduce the amount of inoculum) is a procedure that is often followed and is highly recommended for managing Armillaria root disease (Morrison \& Mallett 1996). Recent studies have investigated the long-term effects (i.e. ranging from 21 to 50 years) of stump and root removal on the incidence of Armillaria root disease in subsequent plantations of various coniferous species in Canada and Scandinavia (Shaw III et al. 2012; Cleary et al. 2013; Morrison et al. 2014, Cruickshank et al. 2018). Except for Shaw III et al. (2012), all studies concluded that this method is effective in reducing the incidence of Armillaria root disease, especially during the first years after the establishment of a new plantation. Shaw III et al. (2012), however, found that stump removal alone has poor long-term benefits and that only more intensive treatments (i.e. maximum removal of roots by machine ripping and removal of visible remaining roots by hand) 
are effective. Thus, it is advisable to consider extensive stump and root removal only in areas with high mortality due to Armillaria root rot, given the costs involved.

Besides disease incidence, several other factors should be evaluated before undertaking stump removal. First, stumps in disease-free areas may also be at risk as they could become colonized by Armillaria inoculum coming from neighboring, infected stands. Some studies have indeed shown that new Armillaria genotypes can become established in first plantation areas where disease symptoms were previously not observed (Rishbeth 1988; Legrand et al. 1996). Cases like this may occur due to colonization by basidiospores originating from other stands. Second, mechanical stump removal is expensive, and likely only cost-effective for trees of high economic value. It should be said that stump harvesting for bioenergy offers an additional financial benefit which may help minimize treatment costs while also reducing the disease impact in the next rotation of the stand (Bogdanski et al. 2018). Third, stump removal may have negative ecological consequences (e.g. loss of organic compounds and nutrients in the soil) and increase the susceptibility of soil to erosion, both of which, in turn, affect the productivity of trees (Norris et al. 2014; Achat et al. 2015). Thus, this measure cannot always be considered as an efficient practical solution for Armillaria root disease management.

An alternative or complementary measure to stump removal could be the ring barking of trees before felling to reduce the amount of carbohydrate stored in the roots and, thus, potentially making them less attractive to Armillaria (Guillaumin \& Legrand 2013). This practice, however, has not proven to be efficient in the presence of abundant rhizomorphs in the soil.

\section{Chemical and biological control}

Other frequently used pre-planting methods to control Armillaria root disease include the treatment of infected soil or plants with biological or chemical agents (reviewed in Baumgartner 
et al. 2011). Chemical treatment consists mainly of soil fumigation using methyl bromide or carbon disulfide which are able to kill fungal mycelium in infected roots. This method has been applied, with variable success, especially in orchards or vineyards. To date, fumigants are generally prohibited due to their high toxicity. Less damaging for the environment, biological control is based on the antagonistic effect of other microbes, especially bacteria and fungi, against Armillaria. This approach aims at decreasing Armillaria incidence and its ability to infect new hosts or colonize dead wood (Dumas 1992; Chapman \& Xiao 2000). Unfortunately, except in some rare cases (Chapman et al. 2004), biological control has proven difficult to apply and has had little success in the field (Raziq and Fox 2003; Baumgartner \& Warnock 2006). Even the new antagonists described in recent studies have so far failed to demonstrate their efficiency at a large scale in the field (Szwajkowska-Michalek et al. 2012; Mesanza et al. 2016; Kwasna \& Szynkiewicz-Wronek 2018).

Tomalak (2017) recently discovered nematodes of the species Bursaphelenchus fraudulentus parasiting Armillaria. In vitro and in vivo artificial inoculations showed that this mycetophagous wood nematode is able to feed, disperse and reproduce in the mycelium of $A$. ostoyae, quickly killing the entire colony. In addition, B. fraudulentus can reproduce within A. ostoyae rhizomorphs, suggesting that these structures could facilitate its spread. The presence of hyperparasites such as this nematode species in nature, might explain the observation of disease foci without further spatial expansion after a first period of high mortality in some forest ecosystems (Durrieu et al. 1985), and, thus, open new opportunities in Armillaria root disease management.

With the continued progress in community analyses using DNA-based methods (e.g. Vayssier-Taussat et al. 2014), it is likely that the network of antagonists interacting with Armillaria species will be better described soon, increasing the options for biological control. The 
identification of the factors that maintain optimal diversity and structure in the microbial soil community, thereby enabling the highest resilience of ecosystems infested by Armillaria, could represent a valid alternative to curative treatment using biological agents that are often difficult to apply (Baumgartner \& Warnock 2006).

\section{Silvicultural measures}

Another possibility for management relies on the use of resistant (i.e. resisting to the pathogen) or tolerant (i.e. coping with the pathogen by surviving and growing) varieties or tree species. Variations in quantitative resistance to Armillaria species have been investigated both among (e.g. Ferguson et al. 2003; Baumgartner et al. 2011; Vyse et al. 2013), and within (e.g. Baumgartner \& Rizzo 2006; Solla et al. 2011; Cruickshank \& Jaquish 2014) host species. Recent advances in genomics could help breeding programs to select traits for resistance in host species (e.g. Plomion et al. 2016), although phenotyping for resistance to Armillaria root disease is a time-consuming process. According to Cruickshank \& Jaquish (2014), breeding programs should focus not only on resistance, but also on tolerance, as both traits have potentially positive effects.

To reduce disease incidence, as well as the risk of rapid adaptation of Armillaria to more resistant tree species or varieties, mixtures of species or varieties should be considered. The use of stand diversification for the control of Armillaria root disease has been studied for a considerable length of time (Gerlach et al. 1997; Fleming et al. 2005). Results have been, however, contradictory, likely also because of the polyphagous nature of the pathogenic Armillaria species considered. Morrison et al. (2014) showed that admixing resistant and susceptible species by the artificial establishment of a stand in British Columbia did not significantly reduce disease impact on the susceptible species over a period of 40 years. Similar findings were reported by Cruickshank et al. (2018). In contrast, a study by Baleshta et al. (2015) 
did reveal how the presence of naturally regenerated broadleaf trees (specifically Betula papyrifera) can reduce mortality due to A. ostoyae and increase productivity of conifer plantations (specifically Pseudotsuga menziesii var. glauca).

The mechanisms that account for how interspersed resistant hosts protect susceptible species have not been clearly identified yet (Iason et al. 2018). On one hand, it could be due to a barrier effect provided by the resistant species and its associated fungal community, reducing the soilborne spread of Armillaria to the more susceptible host species (i.e. associational resistance, Barbosa et al. 2009). On the other hand, the reduced density of the susceptible species may limit root contacts and the transmission of the pathogen (i.e. dilution effect; Prospero \& Cleary 2017). Complex responses were obtained when different densities of resistant and susceptible species were tested (Baleshta et al. 2015; Metslaid et al. 2018). In both studies, an optimal density of resistant or susceptible species was found, suggesting an equilibrium between the effect of competition among susceptible and resistant species and the probability of disease spread. It is likely that these optimal densities vary along with factors such as the type of admixture, the particular Armillaria species, and climatic factors (Nguyen et al. 2016). Thus, additional studies are required in order to draw firm conclusions on the real benefit of admixture.

\section{Integrated management}

Given the ability of Armillaria to disperse among stands, Armillaria root disease management should instead be considered at a regional scale, and not merely at the stand level. For instance, recent epidemiological and population genetic approaches have suggested that the rapid, massive and dense plantation of maritime pine (Pinus pinaster) in south-western France in the $19^{\text {th }}$ century may have offered an opportunity for A. ostoyae to adapt to this intensive monoculture 
forest, and thus, to rapidly expand from the pre-existing forest areas (Labbé et al. 2015; Labbé et al. 2017a).

Considering the modern context of agricultural intensification (i.e. monocultures in large areas without cultural rotations) and the variability in virulence among Armillaria genotypes and species (Prospero et al. 2004; Heinzelmann et al. 2017b; Labbé et al. 2017b), the evolutionary potential for higher virulence in the genus Armillaria should receive more attention. In this regard, an important role could also be played by the reservoir of inoculum in dead woody substrate (Soularue et al. 2017). Because most problems associated with Armillaria root disease are observed in plantations or intensively managed forests, a complementary management strategy could be to foster natural regeneration in stands with low mortality. Although natural regeneration is sometimes difficult to achieve, for example because of browsing pressure by ungulates, it has at least two major benefits. First, this process favors the selection of resistant individuals and likely the establishment of a less favorable microbial community for Armillaria. Second, natural stand regeneration has lower economic costs relative to plantations. However, the efficiency of this strategy needs to be investigated further in stands with high mortality, because contrasting results are reported (Bace et al. 2012; Nevalainen 2017).

\section{Further research perspectives}

In the near future, next generation sequencing and its numerous applications will most likely continue to gain importance for Armillaria research and infiltrate its various disciplines. The amount of data generated with these recent technologies will provide ample opportunities to tackle old questions from a new perspective. For example, generating a collection of high-quality genomes of different Armillaria species may help to resolve the genomic specificities of Armillaria species with different ecological strategies (e.g. parasitic vs. saprotrophic). 
Furthermore, comparing Armillaria genomes with those of other root-rot pathogens (e.g. Heterobasidion or Phellinus spp.) and purely saprotrophic fungi may permit the identification of genes involved in pathogenesis and wood degradation (e.g. Suzuki et al. 2012; Kües et al. 2015). Further, establishing transcriptomic data sets that cover the entire infection process from epiphytic growth of rhizomorphs on roots, to root penetration, and its establishment in the root, may help to uncover the molecular processes taking place at the pathogen-host interface.

Genomic data may also be used to infer the phylogeny of the genus in more detail and help to resolve current taxonomic issues and the evolutionary processes at the foundation of the fascinating radiation of Armillaria species around the world. Moreover, using a genome-based approach will enable the assessment of population dynamics and factors that impact the variability of populations at much higher resolution than in current population genetic studies. A more comprehensive reconstruction of population dynamics will, for example, lead to a better understanding of how increased host availability (e.g. large plantations) may lead to population expansion and higher virulence, thus improving the risk prediction of future large outbreaks (Labbé et al. 2017a; Labbé et al. 2017b). Genomic studies may also greatly help identify genomic regions under selection by comparing Armillaria populations in different climatic and host contexts using the so-called "reverse ecology" approach (Ellison et al. 2011) as a complement to the transcriptomic approach discussed above.

A key issue for an improved understanding of the evolutionary dynamics of Armillaria populations is to link genomic and phenotypic variation, and to understand the importance of the phenotypic variation for the pathogen and its interaction with hosts. However, phenotyping larger sets of isolates, for example, for virulence, one of the most studied traits in Armillaria, is still a considerable challenge because the currently used method (i.e. inoculation of potted seedlings; Morrison 2004; Prospero et al. 2004; Heinzelmann et al. 2017b; Labbé et al. 2017b) is time 
consuming, in terms of preparation and experiment duration. Recent attempts to simplify the virulence screening of Armillaria isolates (Baumgartner et al. 2010a; Ford et al. 2017) are only partially conclusive. In addition, it will be important to develop tools for functional gene validation, which would finally allow us to demonstrate the causative role of candidate genes for the targeted phenotypes.

Overall, it will be crucial for upcoming research to consider a holistic approach that considers the pathogen, the host, and the environment, as well as the complex interactions among them. As outlined in this review, the ecological strategy and disease outcome of Armillaria species varies depending on the environmental context. Extending recently developed models by integrating the different stages of the life cycle of Armillaria, information about pathogen-host interactions, climatic and environmental variables, and simulating long evolutionary timeframes (Soularue et al. 2017), may be a promising approach to predict the outcomes of different environmental and climatic scenarios. Here also, however, field investigations and experimental research will be necessary to obtain baseline data to feed and optimize the models. For example, as outlined in this review, several aspects of the Armillaria life cycle are still poorly known (e.g. conditions and substrate for basidiospore germination), and resolving these questions would significantly improve model accuracy.

Finally, the major challenge will be to translate the insights gained in the various fields of Armillaria research into control strategies to mitigate the impact of Armillaria root disease in current and future woody ecosystems. Tree species admixture and natural regeneration appear to be promising strategies to increase host diversity and promote a more diverse microbial soil community, thereby reducing the impact of Armillaria root disease. However, many questions remain unanswered. As several recent studies presented in this review have shown, the interaction between Armillaria, its hosts, and the environment is complex and difficult to predict. 


\section{Acknowledgements}

We thank C. Gautschi for English revision of the manuscript and the two anonymous reviewers for the helpful comments on the manuscript.

\section{References}

Abomo-Ndongo S, Guillaumin JJ. 1997. Somatic incompatibility among African Armillaria isolates. Eur J Forest Pathol. 27:201-206.

Achat DL, Deleuze C, Landmann G, Pousse N, Ranger J, Augusto L. 2015. Quantifying consequences of removing harvesting residues on forest soils and tree growth - a meta-analysis. For Ecol Manage. 348:124-141.

Aguin-Casal O, Sainz-Oses MJ, Mansilla-Vazquez JP. 2004. Armillaria species infesting vineyards in northwestern Spain. Eur J Plant Pathol. 110:683-687.

Akcapinar GB, Kappel L, Sezerman OU, Seidl-Seiboth V. 2015. Molecular diversity of LysM carbohydrate-binding motifs in fungi. Curr Genet. 61:103-113.

Anderson JB, Ullrich RC. 1979. Biological species of Armillaria mellea in North America. Mycologia $71: 402-414$

Anderson JB, Korhonen K, Ullrich RC. 1980. Relationships between European and North American biological species of Armillaria mellea. Exp Mycol. 4:78-86.

Anderson JB. 1986. Biological species of Armillaria in North America: redesignation of group IV and group VIII and enumeration of voucher strains for other groups. Mycologia 78:837-839.

Anderson JB, Stasovski E. 1992. Molecular phylogeny of Northern Hemisphere species of Armillaria. Mycologia 84:505-516.

Anderson JB, Catona S. 2014. Genomewide mutation dynamic within a long-lived individual of Armillaria gallica. Mycologia 106:642-648. 
Antonin V, Tomsovsky M, Sedlak P, Majek T, Jankovsky L. 2009. Morphological and molecular characterization of the Armillaria cepistipes - A. gallica complex in the Czech Republic and Slovakia. Mycol Prog. 8:259-271.

Aslam AJ, Magel EA. 2018. Influence of drought and season on compartmentalization of black locust (Robinia pseudoacacia L.) inoculated with Armillaria mellea. Eur J Plant Pathol.152:21-31.

Bace R, Svoboda M, Pouska V, Janda P, Cervenka J. 2012. Natural regeneration in Central-European subalpine spruce forests: which logs are suitable for seedling recruitment? For Ecol Manage. $266: 254-262$.

Bakys R, Vasiliauskas A, Ihrmark K, Stenlid J, Menkis A, Vasaitis R. 2011. Root rot, associated fungi and their impact on health condition of declining Fraxinus excelsior stands in Lithuania. Scand $\mathbf{J}$ Forest Res. 26:128-135.

Baleshta KE, Simard SW, Roach WJ. 2015. Effects of thinning paper birch on conifer productivity and understory plant diversity. Scand J Forest Res. 30:699-709.

Banik MT, Burdsall HH. 1998. Assessment of compatibility among Armillaria cepistipes, A. sinapina, and North American biological species X and XI, using culture morphology and molecular biology. Mycologia 90:798-805.

Barbosa P, Hines J, Kaplan I, Martinson H, Szczepaniec A, Szendrei Z. 2009. Associational resistance and associational susceptibility: having right or wrong neighbors. Annu Rev Ecol Evol Syst. 40:1-20.

Baumgartner K, Rizzo DM. 2001. Ecology of Armillaria spp. in mixed-hardwood forests of California. Plant Dis. 85:947-951.

Baumgartner K, Rizzo DM. 2002. Spread of Armillaria root disease in a California vineyard. Am J Enol Vitic. 53:197-203.

Baumgartner K, Rizzo DM. 2006. Relative resistance of grapevine rootstocks to Armillaria root disease. Am J Enol Vitic. 57:408-414.

Baumgartner K, Warnock AE. 2006. A soil inoculant inhibits Armillaria mellea in vitro and improves productivity of grapevines with root disease. Plant Dis. 90:439-444. 
Baumgartner K, Bhat R, Fujiyoshi P. 2010a. A rapid infection assay for Armillaria and real-time PCR quantitation of the fungal biomass in planta. Fungal Biol. 114:107-119.

Baumgartner K, Fujiyoshi P, Foster GD, Bailey AM. 2010b. Agrobacterium tumefaciens-mediated transformation for investigation of somatic recombination in the fungal pathogen Armillaria mellea. Appl Environ Microbiol. 76:7990-7996.

Baumgartner K, Travadon R, Bruhn J, Bergemann SE. 2010c. Contrasting patterns of genetic diversity and population structure of Armillaria mellea sensu stricto in the Eastern and Western United States. Phytopathology 100:708-718.

Baumgartner K, Coetzee MPA, Hoffmeister D. 2011. Secrets of the subterranean pathosystem of Armillaria. Mol Plant Pathol. 12:515-534.

Baumgartner K, Baker BR, Korhonen K, Zhao J, Hughes KW, Bruhn J, Bowman TS, Bergemann SE. 2012. Evidence of natural hybridization among homothallic members of the basidiomycete Armillaria mellea sensu stricto. Fungal Biol. 116:677-691.

Bendel M, Kienast F, Rigling D. 2006a. Genetic population structure of three Armillaria species at the landscape scale: a case study from Swiss Pinus mugo forests. Mycol Res. 110:705-712.

Bendel M, Kienast F, Rigling D, Bugmann H. 2006b. Impact of root-rot pathogens on forest succession in unmanaged Pinus mugo stands in the Central Alps. Can J For Res. 36:2666-2674.

Bérubé JA, Dessureault M. 1989. Morphological studies of the Armillaria mellea complex - 2 new species, Armillaria gemina and Armillaria calvescens. Mycologia 81:216-225.

Bérubé JA, Dessureault M, Berthelay S, Guillaumin JJ. 1996. Interfertility between Armillaria cepistipes and A. sinapina. Phytoprotection 77:67-74.

Bogdanski BEC, Cruickshank M, Di Lucca CM, Becker E. 2018. Stumping out tree root disease - An economic analysis of controlling root disease, including its effects on carbon storage in southern British Columbia. For Ecol Manage. 409:129-147.

Bohnert M, Miethbauer S, Dahse HM, Ziemen J, Nett M, Hoffmeister D. 2011. In vitro cytotoxicity of melleolide antibiotics: structural and mechanistic aspects. Bioorg Med Chem Lett. 21:2003-2006. 
Bohnert M, Nuetzmann HW, Schroeckh V, Horn F, Dahse HM, Brakhage AA, Hoffmeister D. 2014a. Cytotoxic and antifungal activities of melleolide antibiotics follow dissimilar structure-activity relationships. Phytochemistry 105:101-108.

Bohnert M, Scherer O, Wiechmann K, Konig S, Dahse HM, Hoffmeister D, Werz O. 2014b. Melleolides induce rapid cell death in human primary monocytes and cancer cells. Bioorg Med Chem. $22: 3856-3861$

Boitard S, Rodriguez W, Jay F, Mona S, Austerlitz F. 2016. Inferring population size history from large samples of genome-wide molecular data - an approximate Bayesian computation approach. PLOS Genet. 12:e1005877.

Brazee NJ, Marra RE, Wick RL. 2012a. Genotypic diversity of Armillaria gallica from mixed oak forests in Massachusetts. Mycologia 104:53-61.

Brazee NJ, Ortiz-Santana B, Banik MT, Lindner DL. 2012b. Armillaria altimontana, a new species from the western interior of North America. Mycologia 104:1200-1205.

Bruhn JN, Mihail JD, Meyer TR. 1998. Armillaria root disease inoculum remaining in young Ontario conifer plantations following root raking or madge rotoclearing. North J Appl For. 15:191-196.

Bruhn JN, Wetteroff JJ, Mihail JD, Kabrick JM, Pickens JB. 2000. Distribution of Armillaria species in upland Ozark Mountain forests with respect to site, overstory species composition and oak decline. Forest Pathol. 30:43-60.

Burrill EA, Worrall JJ, Wargo PM, Stehman SV. 1999. Effects of defoliation and cutting in eastern oak forests on Armillaria spp. and a competitor, Megacollybia platyphylla. Can J For Res. 29:347-355.

Carvalho DB, Smith ML, Anderson JB. 1995. Genetic exchange between diploid and haploid mycelia of Armillaria gallica. Mycol Res. 99:641-647.

Cha JY, Igarashi T. 1995. A note on Armillaria mellea subsp. nipponica subsp. nov. in Japan. Mycoscience 36:143-146. 
Chandelier A, Gerarts F, San Martin G, Herman M, Delahaye L. 2016. Temporal evolution of collar lesions associated with ash dieback and the occurrence of Armillaria in Belgian forests. Forest Pathol. 46:289-297.

Chapman B, Xiao G. 2000. Inoculation of stumps with Hypholoma fasciculare as a possible means to control Armillaria root disease. Can J Bot. 78:129-134.

Chapman B, Xiao GP, Myers S. 2004. Early results from field trials using Hypholoma fasciculare to reduce Armillaria ostoyae root disease. Can J Bot. 82:962-969.

Chybicki IJ, Burczyk J. 2009. Simultaneous estimation of null alleles and inbreeding coefficients. J Hered. 100:106-113.

Cienciala E, Tumajer J, Zatloukal V, Beranová J, Holá Š, Hůnová I, Russ R. 2017. Recent spruce decline with biotic pathogen infestation as a result of interacting climate, deposition and soil variables. Eur J For Res. 136:307-317.

Cleary MR, Arhipova N, Morrison DJ, Thomsen IM, Sturrock RN, Vasaitis R, Gaitnieks T, Stenlid J. 2013. Stump removal to control root disease in Canada and Scandinavia: a synthesis of results from long-term trials. For Ecol Manage. 290:5-14.

Clinton BD, Boring LR, Swank WT. 1993. Canopy gap characteristics and drought influences in oak forests of the Coweeta Basin. Ecology 74:1551-1558.

Coetzee MPA, Wingfield BD, Bloomer P, Ridley GS, Kile GA, Wingfield MJ. 2001a. Phylogenetic relationships of Australian and New Zealand Armillaria species. Mycologia 93:887-896.

Coetzee MPA, Wingfield BD, Harrington TC, Steimel O, Coutinho TA, Wingfield MJ. 2001b. The root rot fungus Armillaria mellea introduced into South Africa by early Dutch settlers. Mol Ecol. 10:387-396.

Coetzee MPA, Wingfield BD, Bloomer P, Ridley GS, Wingfield MJ. 2003. Molecular identification and phylogeny of Armillaria isolates from South America and Indo-Malaysia. Mycologia 95:285-293.

Coetzee MPA, Wingfield BD, Bloomer P, Wingfield MJ. 2005a. Phylogenetic analyses of DNA sequences reveal species amongst isolates of Armillaria from Africa. Mycol Res. 109:1223-1234. 
Coetzee MPA, Wingfield BD, Kirisits T, Chhetri DB, Bloomer P, Wingfield MJ. 2005b. Identification of Armillaria isolates from Bhutan based on DNA sequence comparisons. Plant Pathol. 54:36-45.

Coetzee MPA, Bloomer P, Wingfield MJ, Wingfield BD. 2011. Paleogene radiation of a plant pathogenic mushroom. PLOS One. 6:e28545.

Coetzee MPA, Wingfield BD, Zhao J, van Coller SJ, Wingfield MJ. 2015. Phylogenetic relationships among biological species of Armillaria from China. Mycoscience 56:530-541.

Coetzee MPA, Musasira NY, Roux J, Roets F, van der Merwe NA, Wingfield MJ. 2018. Armillaria root rot spreading into a natural woody ecosystem in South Africa. Plant Pathol. 67:883-891.

Collins C, Keane TM, Turner DJ, O'Keeffe G, Fitzpatrick DA, Doyle S. 2013. Genomic and proteomic dissection of the ubiquitous plant pathogen, Armillaria mellea: toward a new infection model system. J Proteome Res. 12:2552-2570.

Cruickshank MG, Morrison DJ, Punja ZK. 1997. Incidence of Armillaria species in precommercial thinning stumps and spread of Armillaria ostoyae to adjacent Douglas-fir trees. Can J For Res. 27:481-490.

Cruickshank MG, Jaquish B. 2014. Resistance and tolerance in juvenile interior Douglas-fir trees Pseudotsuga menziesii var. glauca artificially inoculated with Armillaria ostoyae. Forest Pathol. 44:362-371.

Cruickshank MG, Filipescu CN. 2017. The interactive effect of root disease and climate on wood properties in halfsibling Douglas-fir families. For Ecol Manage. 392:58-67.

Cruickshank MG, Filipescu CN, Sturrock RN. 2018. The effect of stump removal and tree admixture on butt decay incidence, damage and wood density in western redcedar. Can J Plant Pathol. 40:368377.Dempster WR. 2017. Impact of climate on juvenile mortality and Armillaria root disease in lodgepole pine. Forest Chron. 93:148-160.

Desprez-Loustau ML, Marçais B, Nageleisen LM, Piou D, Vannini A. 2006. Interactive effects of drought and pathogens in forest trees. Ann For Sci. 63:597-612. 
Desprez-Loustau ML, Aguayo J, Dutech C, Hayden KJ, Husson C, Jakushkin B, Marçais B, Piou D, Robin C, Vacher C. 2016. An evolutionary ecology perspective to address forest pathology challenges of today and tomorrow. Ann For Sci. 73:45-67.

Dettman JR, van der Kamp BJ. 2001a. The population structure of Armillaria ostoyae and Armillaria sinapina in the central interior of British Columbia. Can J Bot. 79:600-611.

Dettman JR, van der Kamp BJ. 2001b. The population structure of Armillaria ostoyae in the southern interior of British Columbia. Can J Bot. 79:612-620.

Drakulic J, Gorton C, Perez-Sierra A, Clover G, Beal L. 2017. Associations between Armillaria species and host plants in UK gardens. Plant Dis. 101:1903-1909.

Duchesne LC, Anderson JB. 1990. Location and direction of transcription of the 5S ribosomal RNA gene in Armillaria. Mycol Res. 94:266-269.

Dukes JS, Pontius J, Orwig D, Garnas JR, Rodgers VL, Brazee N, Cooke B, Theoharides KA, Stange EE, Harrington R et al. 2009. Responses of insect pests, pathogens, and invasive plant species to climate change in the forests of northeastern North America: what can we predict? Can J For Res. $39: 231-248$.

Dumas MT. 1992. Inhibition of Armillaria by bacteria isolated from soils of the boreal mixedwood forest of Ontario. Eur J Forest Pathol. 22:11-18.

Durrieu G, Beneteau A, Niocel S. 1985. Armillaria obscura dans l'écosystème forestier de Cerdagne. Eur J Forest Pathol. 15:350-355.

Dutech C, Labbé F, Capdevielle X, Lung-Escarmant B. 2017. Genetic analysis reveals efficient sexual spore dispersal at a fine spatial scale in Armillaria ostoyae, the causal agent of root-rot disease in conifers. Fungal Biol. 121:550-560.

Dyderski MK, Paz S, Frelich LE, Jagodzinski AM. 2018. How much does climate change threaten European forest tree species distributions? Glob Change Biol. 24:1150-1163.

Edman M, Gustafsson M, Stenlid J, Jonsson BG, Ericson L. 2004. Spore deposition of wood-decaying fungi: importance of landscape composition. Ecography 27:103-111. 
Elías-Román RD, Guzmán-Plazola RA, Klopfenstein NB, Alvarado-Rosales D, Calderón-Zavala G, Mora-Aguilera JA, Kim MS, García-Espinosa R. 2013. Incidence and phylogenetic analyses of Armillaria spp. associated with root disease in peach orchards in the State of Mexico, Mexico. Forest Pathol. 43:390-401.

Elías-Román RD, Medel-Ortiz R, Alvarado-Rosales D, Hanna JW, Ross-Davis AL, Kim M-S, Klopfenstein NB. 2018. Armillaria mexicana, a newly described species from Mexico. Mycologia $110: 347-360$.

Ellison CE, Hall C, Kowbel D, Welch J, Brem RB, Glass NL, Taylor JW. 2011. Population genomics and local adaptation in wild isolates of a model microbial eukaryote. Proc Natl Acad Sci USA. 108:2831-2836.

Enderle R, Sander F, Metzler B. 2017. Temporal development of collar necroses and butt rot in association with ash dieback. iForest. 10:529-536.

Ferguson BA, Dreisbach TA, Parks CG, Filip GM, Schmitt CL. 2003. Coarse-scale population structure of pathogenic Armillaria species in a mixed-conifer forest in the Blue Mountains of northeast Oregon. Can J For Res. 33:612-623.

Fischer MC, Rellstab C, Leuzinger M, Roumet M, Gugerli F, Shimizu KK, Holderegger R, Widmer A. 2017. Estimating genomic diversity and population differentiation - an empirical comparison of microsatellite and SNP variation in Arabidopsis halleri. BMC Genomics 18:69.

Fleming RL, Mossa DS, Marek GT. 2005. Upland black spruce stand development 17 years after cleaning and precommercial thinning. For Chron. 81:31-41.

Ford KL, Baumgartner K, Henricot B, Bailey AM, Foster GD. 2015. A reliable in vitro fruiting system for Armillaria mellea for evaluation of Agrobacterium tumefaciens transformation vectors. Fungal Biol. 119:859-869.

Ford KL, Baumgartner K, Henricot B, Bailey AM, Foster GD. 2016. A native promoter and inclusion of an intron is necessary for efficient expression of GFP or mRFP in Armillaria mellea. Sci Rep. 6:29226. 
Ford KL, Henricot B, Baumgartner K, Bailey AM, Foster GD. 2017. A faster inoculation assay for Armillaria using herbaceous plants. J Horticult Sci Biotechnol. 92:39-47.

Ford KL, Bourquin FHM. 2018. A CRISPER way to edit the honey fungus. GARNet Gene Editing Workshop, University of Bristol.

Gerlach JP, Reich PB, Puettmann K, Baker T. 1997. Species, diversity, and density affect tree seedling mortality from Armillaria root rot. Can J For Res. 27:1509-1512.

Gregory SC, Rishbeth J, Shaw III CG. 1991. Pathogenicity and virulence. In: Shaw III CG, Kile GA, editors. Armillaria root disease. Agricultural Handbook No 691. Washington D.C.: USDA Forest Service; p. 76-87.

Gross A, Holdenrieder O, Pautasso M, Queloz V, Sieber TN. 2014. Hymenoscyphus pseudoalbidus, the causal agent of European ash dieback. Mol Plant Pathol. 15:5-21.

Guichoux E, Lagache L, Wagner S, Chaumeil P, Leger P, Lepais O, Lepoittevin C, Malausa T, Revardel E, Salin F et al. 2011. Current trends in microsatellite genotyping. Mol Ecol Resour. 11:591-611.

Guillaumin JJ, Lung B, Romagnesi H, Marxmüller H, Lamoure D, Durrieu G, Berthelay S, Mohammed C. 1985. Systématique des Armillaires du groupe mellea. Conséquences phytopathologiques. Eur J Forest Pathol. 15:268-277.

Guillaumin JJ, Mohammed C, Anselmi N, Courtecuisse R, Gregory SC, Holdenrieder O, Intini M, Lung B, Marxmüller H, Morrison DJ et al. 1993. Geographical distribution and ecology of the Armillaria species in western Europe. Eur J Forest Pathol. 23:321-341.

Guillaumin JJ. 2005. Chapter 5, Systèmes sexuels et cycles caryologiques. In: Guillaumin JJ, Legrand P, Lung-Escarmant B et al., editors. L'armillaire et le pourridié-agaric des végétaux ligneux. Paris: INRA; p. 85-101.

Guillaumin JJ, Botton B. 2005. Chapter 9, Ontogénie des armillaires. In: Guillaumin JJ, Legrand P, LungEscarmant B et al., editors. L'armillaire et le pourridié-agaric des végétaux ligneux. Paris: INRA; p. 151-175. 
Guillaumin JJ, Legrand P. 2005. Chapter 10, Cycle infectieux de l'armillaire - Stratégie biologique des espèces européennes. In: Guillaumin JJ, Legrand P, Lung-Escarmant B et al., editors. L'armillaire et le pourridié-agaric des végétaux ligneux. Paris: INRA; p. 177-201.

Guillaumin JJ, Legrand P, Lung-Escarmant B, Botton B. 2005. L'armillaire et le pourridié-agaric des végétaux ligneux. Paris: INRA.

Guillaumin JJ, Legrand P. 2013. Armillaria root rots. In: Gonthier P, Nicolotti G, editors. Infectious forest diseases. Wallingford: CABI Publishing; p. 159-177.

Guo T, Wang HC, Xue WQ, Zhao J, Yang ZL. 2016. Phylogenetic analyses of Armillaria reveal at least 15 phylogenetic lineages in China, seven of which are associated with cultivated Gastrodia elata. PLOS One. 11:e0154794.

Haavik LJ, Billings SA, Guldin JM, Stephen FM. 2015. Emergent insects, pathogens and drought shape changing patterns in oak decline in North America and Europe. For Ecol Manage. 354:190-205.

Hanewinkel M, Cullmann DA, Schelhaas M-J, Nabuurs G-J, Zimmermann NE. 2012. Climate change may cause severe loss in the economic value of European forest land. Nat Clim Change. 3:203207.

Harrington TC, Worrall JJ, Baker FA. 1992. Armillaria. In: Singleton LL, Mihail JD, Rush CM, editors. Methods for research on soilborne phytopathogenic fungi. St. Paul, Minnesota: APS Press; p. 8185.

Harrington TC, Wingfield BD. 1995. A PCR-based identification method for species of Armillaria. Mycologia 87:280-288.

Hasegawa E, Ota Y, Hattori T, Kikuchi T. 2010. Sequence-based identification of Japanese Armillaria species using the elongation factor-1 alpha gene. Mycologia 102:898-910.

Hasegawa E, Ota Y, Hattori T, Sahashi N, Kikuchi T. 2011. Ecology of Armillaria species on conifers in Japan. Forest Pathol. 41:429-437.

Heinzelmann R, Rigling D, Prospero S. 2012. Population genetics of the wood-rotting basidiomycete Armillaria cepistipes in a fragmented forest landscape. Fungal Biol. 116:985-994. 
Heinzelmann R, Rigling D. 2016. Mycelial fan formation of three sympatric Armillaria species on excised stem segments of Picea abies. Forest Pathol. 46:187-199.

Heinzelmann R, Croll D, Zoller S, Sipos G, Münsterkötter M, Güldener U, Rigling D. 2017a. Highdensity genetic mapping identifies the genetic basis of a natural colony morphology mutant in the root rot pathogen Armillaria ostoyae. Fungal Genet Biol. 108:44-54.

Heinzelmann R, Prospero S, Rigling D. 2017b. Virulence and stump colonization ability of Armillaria borealis on norway spruce seedlings in comparison to sympatric Armillaria species. Plant Dis. $101: 470-479$.

Heinzelmann R, Prospero S, Rigling D. 2018. Frequent diploidisation of haploid Armillaria ostoyae strains in an outdoor inoculation experiment. Fungal Biol. 122:147-155.

Hewitt G. 2000. The genetic legacy of the Quaternary ice ages. Nature 405:907-913.

Holuša J, Lubojacký J, Čurn V, Tonka T, Lukášová K, Horák J. 2018. Combined effects of drought stress and Armillaria infection on tree mortality in Norway spruce plantations. For Ecol Manage. 427:434-445.

Hood IA, Petrini LE, Gardner JF. 2008. Colonisation of woody material in Pinus radiata plantations by Armillaria novae-zelandiae basidiospores. Australas Plant Path. 37:347-352.

Hood IA, Ramsfield TD. 2016. Armillaria aotearoa species nova. N Z J For Sci. 46:2.

Horsley SB, Long RP, Bailey SW, Hallett RA, Wargo PM. 2002. Health of eastern North American sugar maple forests and factors affecting decline. North J Appl For. 19:34-44.

Husson C, Cael O, Grandjean JP, Nageleisen LM, Marçais B. 2012. Occurrence of Hymenoscyphus pseudoalbidus on infected ash logs. Plant Pathol. 61:889-895.

Iason GR, Taylor J, Helfer S. 2018. Community-based biotic effects as determinants of tree resistance to pests and pathogens. For Ecol Manage. 417:301-312.

Keca N, Klopfenstein NB, Kim MS, Solheim H, Woodward S. 2015. Initial characterization of an unidentified Armillaria isolate from Serbia using LSU-IGS1 and TEF-1-alpha genes. Forest Pathol. 45:120-126. 
Kile GA. 1983. Identification of genotypes and the clonal development of Armillaria luteobubalina (Watling \& Kile) in eucalypt forests. Aust J Bot. 31:657-671.

Kile GA, Guillaumin JJ, Mohammed C, Watling R. 1994. Biogeography and pathology of Armillaria. In: Johansson M, Stenlid J, editors. Proceedings of the 8th International Conference on Root and Butt Rots, Wik, Sweden, and Haikko, Finland, 9-16 August 1993. Upsala: Swedish University of Agricultural Sciences; p. 411-436.

Kim MS, Klopfenstein NB, McDonald GI, Arumuganathan K, Vidaver LK. 2000. Characterization of North American Armillaria species by nuclear DNA content and RFLP analysis. Mycologia 92:874-883.

Kim MS, Klopfenstein NB, McDonald GI, Arumuganathan K, Vidaver AK. 2001. Use of flow cytometry, fluorescence microscopy, and PCR-based techniques to assess intraspecific and interspecific matings of Armillaria species. Mycol Res. 105:153-163.

Kim MS, Klopfenstein NB, Hanna JW, McDonald GI. 2006. Characterization of North American Armillaria species: genetic relationships determined by ribosomal DNA sequences and AFLP markers. Forest Pathol. 36:145-164.

Kim MS, Klopfenstein NB. 2011. Molecular Identification of Armillaria gallica from the Niobrara Valley Preserve in Nebraska. J Phytopathol. 159:69-71.

Klopfenstein NB, Kim MS, Hanna JW, Richardson BA, Lundquist JE. 2009. Approaches to predicting potential impacts of climate change on forest disease: an example with Armillaria root disease. Fort Collins, CO: U.S. Department of Agriculture, Forest Service, Rocky Mountain Research Station. (Research Paper RMRS-RP-76).

Klopfenstein NB, Stewart JE, Ota Y, Hanna JW, Richardson BA, Ross-Davis AL, Elías-Román RD, Korhonen K, Keča N, Iturritxa E et al. 2017. Insights into the phylogeny of Northern Hemisphere Armillaria: Neighbor-net and Bayesian analyses of translation elongation factor 1- $\alpha$ gene sequences. Mycologia 109:75-91. 
Koch RA, Wilson AW, Séné O, Henkel TW, Aime MC. 2017. Resolved phylogeny and biogeography of the root pathogen Armillaria and its gasteroid relative, Guyanagaster. BMC Evol Biol. 17:33.

Kombrink A, Thomma BPHJ. 2013. LysM effectors: Secreted proteins supporting fungal life. PLOS Pathog. 9:e1003769.

Korhonen K. 1978. Interfertility and clonal size in the Armillariella mellea complex. Karstenia 18:31-42.

Kromroy KW, Blanchette RA, Grigal DF. 2005. Armillaria species on small woody plants, small woody debris, and root fragments in red pine stands. Can J For Res. 35:1487-1495.

Kubiak K, Zolciak A, Damszel M, Lech P, Sierota Z. 2017. Armillaria pathogenesis under climate changes. Forests 8:100.

Kües U, Nelson DR, Liu C, Yu GJ, Zhang JH, Li JQ, Wang XC, Sun H. 2015. Genome analysis of medicinal Ganoderma spp. with plant-pathogenic and saprotrophic life-styles. Phytochemistry 114:18-37.

Kwasna H, Szynkiewicz-Wronek A. 2018. Culturable microfungi inhibitory to Armillaria rhizomorph formation from Fagus sylvatica stump roots and soil. J Phytopathol. 166:314-323.

La Porta N, Capretti P, Thomsen IM, Kasanen R, Hietala AM, Von Weissenberg K. 2008. Forest pathogens with higher damage potential due to climate change in Europe. Can J Plant Pathol. $30: 177-195$.

Labbé F, Marçais B, Dupouey JL, Belouard T, Capdevielle X, Piou D, Robin C, Dutech C. 2015. Preexisting forests as sources of pathogens? The emergence of Armillaria ostoyae in a recently planted pine forest. For Ecol Manage. 357:248-258.

Labbé F, Fontaine MC, Robin C, Dutech C. 2017a. Genetic signatures of variation in population size in a native fungal pathogen after the recent massive plantation of its host tree. Heredity 119:402-410.

Labbé F, Lung-Escarmant B, Fievet V, Soularue J-P, Laurent C, Robin C, Dutech C. 2017b. Variation in traits associated with parasitism and saprotrophism in a fungal root-rot pathogen invading intensive pine plantations. Fungal Ecol. 26:99-108. 
Legrand P, Ghahari S, Guillaumin J-J. 1996. Occurrence of genets of Armillaria spp. in four mountain forests in Central France: the colonization strategy of Armillaria ostoyae. New Phytol. 133:321332.

Lehtijarvi A, Dogmus-Lehtijarvi HT, Kaya AGA, Unal S, Woodward S. 2017. Armillaria ostoyae in managed coniferous forests in Kastamonu in Turkey. Forest Pathol. 47:e12364.

Lenz HD, Bartha B, Strasser L, Lemme H. 2016. Development of ash dieback in south-eastern Germany and the increasing occurrence of secondary pathogens. Forests 7:41.

Lima MLA, Asai T, Capelari M. 2008. Armillaria paulensis: a new South American species. Mycol Res. 112:1122-1128.

Loo J. 2009. Ecological impacts of non-indigenous invasive fungi as forest pathogens. Biol Invasions. 11:81-96.

Lung-Escarmant B, Guyon D. 2004. Temporal and spatial dynamics of primary and secondary infection by Armillaria ostoyae in a Pinus pinaster plantation. Phytopathology 94:125-131.

Maphosa L, Wingfield BD, Coetzee MPA, Mwenje E, Wingfield MJ. 2006. Phylogenetic relationships among Armillaria species inferred from partial elongation factor 1-alpha DNA sequence data. Australas Plant Path. 35:513-520.

Marçais B, Breda N. 2006. Role of an opportunistic pathogen in the decline of stressed oak trees. J Ecol. 94:1214-1223.

Marçais B, Husson C, Godart L, Caël O. 2016. Influence of site and stand factors on Hymenoscyphus fraxineus-induced basal lesions. Plant Pathol. 65:1452-1461.

Matheny PB, Curtis JM, Hofstetter V, Aime MC, Moncalvo JM, Ge ZW, Yang ZL, Slot JC, Ammirati JF, Baroni TJ et al. 2006. Major clades of Agaricales: a multilocus phylogenetic overview. Mycologia 98:982-995.

May TW. 2017. Report of the Nomenclature Committee for Fungi - 20. Taxon 66:483-495. 
Mayden RL. 1997. A hierarchy of species concepts: the denouement in the saga of the species problem. In: Claridge MF, Dawah HA, Wilson MR, editors. Species: The units of diversity. London, New York: Chapman \& Hall; p. 381-423.

Mesanza N, Iturritxa E, Patten CL. 2016. Native rhizobacteria as biocontrol agents of Heterobasidion annosum s.s. and Armillaria mellea infection of Pinus radiata. Biol Control. 101:8-16.

Mesanza N, Patten CL, Iturritxa E. 2017. Distribution and characterization of Armillaria complex in Atlantic forest ecosystems of Spain. Forests 8:235.

Metslaid M, Granhus A, Scholten J, Fjeld D, Solheim H. 2018. Long-term effects of single-tree selection on the frequency and population structure of root and butt rot in uneven-sized Norway spruce stands. For Ecol Manage. 409:509-517.

Misiek M, Williams J, Schmich K, Huttel W, Merfort I, Salomon CE, Aldrich CC, Hoffmeister D. 2009. Structure and Cytotoxicity of Arnamial and Related Fungal Sesquiterpene Aryl Esters. J Nat Prod. $72: 1888-1891$.

Misiek M, Hoffmeister D. 2012. Sesquiterpene aryl ester natural products in North American Armillaria species. Mycol Prog. 11:7-15.

Morrison DJ, Chu D, Johnson ALS. 1985. Species of Armillaria in British-Columbia. Can J Plant Pathol. $7: 242-246$.

Morrison DJ, Mallett K. 1996. Silvicultural management of Armillaria root disease in western Canadian forests. Can J Plant Pathol. 18:194-199.

Morrison DJ. 2004. Rhizomorph growth habit, saprophytic ability and virulence of 15 Armillaria species. Forest Pathol. 34:15-26.

Morrison DJ. 2011. Epidemiology of Armillaria root disease in Douglas-fir plantations in the cedarhemlock zone of the southern interior of British Columbia. Forest Pathol. 41:31-40.

Morrison DJ, Cruickshank MG, Lalumiere A. 2014. Control of laminated and Armillaria root diseases by stump removal and tree species mixtures: amount and cause of mortality and impact on yield after 40 years. For Ecol Manage. 319:75-98. 
Motta JJ, Korhonen K. 1986. A note on Armillaria mellea and Armillaria bulbosa from the Middle Atlantic States. Mycologia 78:471-474.

Nevalainen S. 2017. Comparison of damage risks in even- and uneven-aged forestry in Finland. Silva Fenn. 51:1741.

Nguyen D, Castagneyrol B, Bruelheide H, Bussotti F, Guyot V, Jactel HE, Jaroszewicz B, Valladares F, Stenlid J, Boberg J. 2016. Fungal disease incidence along tree diversity gradients depends on latitude in European forests. Ecol Evol. 6:2426-2438.

Norris CE, Hogg KE, Maynard DG, Curran MP. 2014. Stumping trials in British Columbia - organic matter removal and compaction effects on tree growth from seedlings to midrotation stands. Can J For Res. 44:1402-1418.

Ota Y, Matsushita N, Nagasawa E, Terashita T, Fukuda K, Suzuki K. 1998. Biological species of Armillaria in Japan. Plant Dis. 82:537-543.

Park KH, Oh SY, Park MS, Kim MS, Klopfenstein NB, Kim NK, Park JY, Kim JJ, Han SK, Lee JK et al. 2018. Re-evaluation of Armillaria and Desarmillaria in South Korea based on ITS/tef1 sequences and morphological characteristics. Forest Pathol. (in press).

Pavlov IN. 2015. Biotic and abiotic factors as causes of coniferous forests dieback in Siberia and Far East. Contemp Probl Ecol. 8:440-456.

Pearce MH, Malajczuk N. 1990. Factors affecting growth of Armillaria luteobubalina rhizomorphs in soil. Mycol Res. 94:38-48.

Pildain MB, Coetzee MPA, Rajchenberg M, Petersen RH, Wingfield MJ, Wingfield BD. 2009. Molecular phylogeny of Armillaria from the Patagonian Andes. Mycol Prog. 8:181-194.

Pildain MB, Coetzee MPA, Wingfield BD, Wingfield MJ, Rajchenberg M. 2010. Taxonomy of Armillaria in the Patagonian forests of Argentina. Mycologia 102:392-403.

Plomion C, Bastien C, Bogeat-Triboulot MB, Bouffier L, Dejardin A, Duplessis S, Fady B, Heuertz M, Le Gac AL, Le Provost G et al. 2016. Forest tree genomics: 10 achievements from the past 10 years and future prospects. Ann For Sci. 73:77-103. 
Power MWP, Ramsfield TD, Hood IA. 2008. Detection of Armillaria basidiospore dispersal. N Z Plant Prot. 61:35-40.

Prospero S, Holdenrieder O, Rigling D. 2003a. Primary resource capture in two sympatric Armillaria species in managed Norway spruce forests. Mycol Res. 107:329-338.

Prospero S, Rigling D, Holdenrieder O. 2003b. Population structure of Armillaria species in managed Norway spruce stands in the Alps. New Phytol. 158:365-373.

Prospero S, Holdenrieder O, Rigling D. 2004. Comparison of the virulence of Armillaria cepistipes and Armillaria ostoyae on four Norway spruce provenances. Forest Pathol. 34:1-14.

Prospero S, Holdenrieder O, Rigling D. 2006. Rhizomorph production and stump colonization by cooccurring Armillaria cepistipes and Armillaria ostoyae: an experimental study. Forest Pathol. $36: 21-31$.

Prospero S, Lung-Escarmant B, Dutech C. 2008. Genetic structure of an expanding Armillaria root rot fungus (Armillaria ostoyae) population in a managed pine forest in southwestern France. Mol Ecol. 17:3366-3378.

Prospero S, Cleary M. 2017. Effects of host variability on the spread of invasive forest diseases. Forests $8: 80$.

Puebla O, Bermingham E, McMillan WO. 2012. On the spatial scale of dispersal in coral reef fishes. Mol Ecol. 21:5675-5688.

Qin GF, Zhao J, Korhonen K. 2007. A study on intersterility groups of Armillaria in China. Mycologia 99:430-441.

Raffaele S, Kamoun S. 2012. Genome evolution in filamentous plant pathogens: why bigger can be better. Nat Rev Micro. 10:417-430.

Raziq F, Fox RTV. 2003. Comparisons between the in vitro and in vivo efficacies of potential fungal antagonists of Armillaria mellea. Biol Agric Hortic. 21:263-276.

Redfern DB, Filip GM. 1991. Inoculum and infection. In: Shaw III CG, Kile GA, editors. Armillaria root disease. Agricultural Handbook No 691. Washington D.C.: USDA Forest Service; p. 48-61. 
Reusch TBH, Hukriede W, Stam WT, Olsen JL. 1999. Differentiating between clonal growth and limited gene flow using spatial autocorrelation of microsatellites. Heredity 83:120-126.

Rishbeth J. 1970. The role of basidiospores in stump infection by Armillaria mellea. In: Tousson TA, Bega RV, Nelson PE, editors. Root diseases and soil-borne pathogens. Berkeley, CA: University of California Press; p. 141-146.

Rishbeth J. 1978. Effects of soil temperature and atmosphere on growth of Armillaria rhizomorphs. Trans Br Mycol Soc. 70:213-220.

Rishbeth J. 1985. Infection cycle of Armillaria and host response. Eur J Forest Pathol. 15:332-341.

Rishbeth J. 1988. Stump infection by Armillaria in first-rotation conifers. Eur J Forest Pathol. 18:401-408.

Rizzo DM, May G. 1994. Nuclear replacement during mating in Armillaria ostoyae (Basidiomycotina). Microbiology 140:2115-2124.

Robene-Soustrade I, Lung-Escarmant B, Chauvin B, Germain R. 1998. Enzyme equipment in the Armillaria ostoyae-Pinus pinaster interaction: relation to host aggression. In: Delatour C, Marçais B, Guillaumin JJ et al., editors. Root and Butt Rots of Forest Trees - 9th International conference on root and butt rots. Paris: INRA; p. 301-310.

Roll-Hansen F. 1985. The Armillaria species in Europe - a literature review. Eur J Forest Pathol. 15:2231.

Ross-Davis AL, Hanna JW, Kim MS, Klopfenstein NB. 2012. Advances toward DNA-based identification and phylogeny of North American Armillaria species using elongation factor-1 alpha gene. Mycoscience 53:161-165.

Ross-Davis AL, Stewart JE, Hanna JW, Kim MS, Knaus BJ, Cronn R, Rai H, Richardson BA, McDonald GI, Klopfenstein NB. 2013. Transcriptome of an Armillaria root disease pathogen reveals candidate genes involved in host substrate utilization at the host-pathogen interface. Forest Pathol. 43:468-477.

Rousset F. 1997. Genetic differentiation and estimation of gene flow from $F$-statistics under isolation-bydistance. Genetics 145:1219-1228. 
Sánchez-Vallet A, Mesters JR, Thomma BPHJ. 2015. The battle for chitin recognition in plant-microbe interactions. FEMS Microbiol Rev. 39:171-183.

Seneviratne SI, Nicholls N, Easterling D, Goodess CM, Kanae S, Kossin J, Luo Y, Marengo J, McInnes $\mathrm{K}$, Rahimi M et al. 2012. Changes in climate extremes and their impacts on the natural physical environment. In: Field CB, Dahe Q, Stocker TF et al., editors. Managing the risks of extreme events and disasters to advance climate change adaptation: special report of the intergovernmental panel on climate change. Cambridge: Cambridge University Press; p. 109-230.

Shaw III CG, Kile GA, editors. 1991. Armillaria root disease. Washington D.C.: USDA Forest Service. (Agricultural Handbook No. 691).

Shaw III CG, Omdal DW, Ramsey-Kroll A, Roth LF. 2012. Inoculum reduction measures to manage Armillaria root disease in a severely infected stand of ponderosa pine in south-central Washington: 35-year results. West J Appl For. 27:25-29.

Sipos G, Prasanna AN, Walter MC, O’Connor E, Bálint B, Krizsán K, Kiss B, Hess J, Varga T, Slot J et al. 2017. Genome expansion and lineage-specific genetic innovations in the forest pathogenic fungi Armillaria. Nat Ecol Evol. 1:1931-1941.

Skovsgaard JP, Thomsen IM, Skovgaard IM, Martinussen T. 2010. Associations among symptoms of dieback in even-aged stands of ash (Fraxinus excelsior L.). Forest Pathol. 40:7-18.

Smith ML, Bruhn JN, Anderson JB. 1992. The fungus Armillaria bulbosa is among the largest and oldest living organisms. Nature 356:428-431.

Solla A, Aguin O, Cubera E, Sampedro L, Mansilla JP, Zas R. 2011. Survival time analysis of Pinus pinaster inoculated with Armillaria ostoyae: genetic variation and relevance of seed and root traits. Eur J Plant Pathol. 130:477-488.

Soularue JP, Robin C, Desprez-Loustau ML, Dutech C. 2017. Short rotations in forest plantations accelerate virulence evolution in root-rot pathogenic fungi. Forests 8:205.

Stoytchev I, Nerud F. 2000. Ligninolytic enzyme complex of Armillaria spp. Folia Microbiol. 45:248-250. 
Sturrock RN. 2012. Climate change and forest diseases: using today's knowledge to address future challenges. For Syst. 21:329-336.

Suzuki H, MacDonald J, Syed K, Salamov A, Hori C, Aerts A, Henrissat B, Wiebenga A, vanKuyk PA, Barry K et al. 2012. Comparative genomics of the white-rot fungi, Phanerochaete carnosa and $P$. chrysosporium, to elucidate the genetic basis of the distinct wood types they colonize. BMC Genomics 13:444.

Szewczyk W, Kwasna H, Behnke-Borowczyk J. 2016. Armillaria population in flood-plain forest of natural pedunculate oak showing oak decline. Pol J Environ Stud. 25:1253-1262.

Szwajkowska-Michalek L, Kwasna H, Lakomy P, Perkowski J. 2012. Inhibition of Armillaria and Heterobasidion growth by Penicillium adametzii isolated from Pinus sylvestris forest soil. Forest Pathol. 42:454-466.

Taylor JW, Jacobson DJ, Kroken S, Kasuga T, Geiser DM, Hibbett DS, Fisher MC. 2000. Phylogenetic species recognition and species concepts in fungi. Fungal Genet Biol. 31:21-32.

Termorshuizen AJ, Arnolds EJM. 1994. Geographical distribution of the Armillaria species in The Netherlands in relation to soil type and hosts. Eur J Forest Pathol. 24:129-136.

Timmermann V, Nagy NE, Hietala AM, Borja I, Solheim H. 2017. Progression of ash dieback in Norway related to tree age, disease history and regional aspects. Baltic For. 23:150-158.

Tomalak M. 2017. Parasitic association of the mycetophagous wood nematode, Bursaphelenchus fraudulentus with the honey fungus Armillaria ostoyae. Forest Pathol. 47:e12325.

Travadon R, Smith ME, Fujiyoshi P, Douhan GW, Rizzo DM, Baumgartner K. 2012. Inferring dispersal patterns of the generalist root fungus Armillaria mellea. New Phytol. 193:959-969.

Tsykun T, Rigling D, Nikolaychuk V, Prospero S. 2012. Diversity and ecology of Armillaria species in virgin forests in the Ukrainian Carpathians. Mycol Prog. 11:403-414.

Tsykun T, Rigling D, Prospero S. 2013. A new multilocus approach for a reliable DNA-based identification of Armillaria species. Mycologia 105:1059-1076. 
Tsykun T, Rellstab C, Dutech C, Sipos G, Prospero S. 2017. Comparative assessment of SSR and SNP markers for inferring the population genetic structure of the common fungus Armillaria cepistipes. Heredity 119:371-380.

Turland NJ, Wiersema JH, Monro AM, Deng Y-F, Zhang L. 2017. XIX International Botanical Congress: report of congress action on nomenclature proposals. Taxon 66:1234-1245.

Vayssier-Taussat M, Albina E, Citti C, Cosson JF, Jacques MA, Lebrun MH, Le Loir Y, Ogliastro M, Petit MA, Roumagnac P et al. 2014. Shifting the paradigm from pathogens to pathobiome: new concepts in the light of meta-omics. Front Cell Infect Microbiol. 4:29.

Volk TJ, Burdsall HHJ. 1995. A nomenclatural study of Armillaria and Armillariella species. Oslo: Fungiflora. (Synopsis Fungorum 8).

Vyse A, Cleary MR, Cameron IR. 2013. Tree species selection revisited for plantations in the Interior Cedar Hemlock zone of southern British Columbia. For Chron. 89:382-391.

Wargo PM. 1972. Defoliation-induced chemical changes in sugar maple roots stimulate growth of Armillaria mellea. Phytopathology 62:1278-1283.

Wargo PM, Harrington TC. 1991. Host stress and susceptibility. In: Shaw III CG, Kile GA, editors. Armillaria root disease. Agricultural Handbook No 691. Washington D.C.: USDA Forest Service; p. $88-101$.

Wargo PM. 1996. Consequences of environmental stress on oak: predisposition to pathogens. Ann Sci For. 53:359-368.

Watling R, Kile GA, Burdsall HH. 1991. Chapter 1, Nomenclature, taxonomy and identification. In: Shaw III CG, Kile GA, editors. Armillaria root disease. Agricultural Handbook No 691. Washington D.C.: USDA Forest Service; p. 1-9.

Whitlock MC, McCauley DE. 1999. Indirect measures of gene flow and migration: $F_{S T} \neq 1 /(4 \mathrm{Nm}+1)$. Heredity 82:117-125.

Wingfield BD, Ambler JM, Coetzee MPA, de Beer ZW, Duong TA, Joubert F, Hammerbacher A, McTaggart AR, Naidoo K, Nguyen HDT et al. 2016. Draft genome sequences of Armillaria 
fuscipes, Ceratocystiopsis minuta, Ceratocystis adiposa, Endoconidiophora laricicola, E. polonica and Penicillium freii DAOMC 242723. IMA Fungus. 7:217-227.

Woods AJ, Heppner D, Kope HH, Burleigh J, Maclauchlan L. 2010. Forest health and climate change: a British Columbia perspective. For Chron. 86:412-422.

Worrall JJ, Sullivan KF, Harrington TC, Steimel JP. 2004. Incidence, host relations and population structure of Armillaria ostoyae in Colorado campgrounds. For Ecol Manage. 192:191-206.

Wright S. 1969. Evolution and the genetics of populations. Volume 2. Theory of gene frequencies. Chicago: The University of Chicago Press.

Xing R, Gao QB, Zhang FQ, Li YH, Fu PC, Zhang JH, Wang JL, Khan G, Chen SL. 2014. Genetic diversity and population structure of Armillaria luteovirens (Physalacriaceae) in Qinghai-Tibet Plateau revealed by SSR markers. Biochem Syst Ecol. 56:1-7. 
Table 1. Summary statistics of the Armillaria genomes reported in Collins et al. (2013), Wingfield et al. (2016) and Sipos et al. (2017).

\begin{tabular}{|c|c|c|c|c|c|c|c|}
\hline Species & Strain & Origin & $\begin{array}{l}\text { Total } \\
\text { length } \\
(\mathrm{Mbp})\end{array}$ & $\begin{array}{l}\text { Number } \\
\text { of } \\
\text { scaffolds }\end{array}$ & $\begin{array}{l}\text { N50 } \\
(\mathrm{Mbp})^{1)}\end{array}$ & $\begin{array}{l}\text { Number } \\
\text { of genes }\end{array}$ & Reference \\
\hline A. cepistipes & $\mathrm{B} 5$ & Europe & 75.50 & 182 & 3.29 & 23,461 & $\begin{array}{l}\text { Sipos et al. } \\
(2017)\end{array}$ \\
\hline A. gallica & Ar21-1 & $\begin{array}{l}\text { North } \\
\text { America }\end{array}$ & 85.34 & 319 & 1.04 & 25,704 & $\begin{array}{l}\text { Sipos et al. } \\
(2017)\end{array}$ \\
\hline A. mellea $^{2)}$ & $\begin{array}{l}\text { DSM } \\
3731\end{array}$ & Europe & 58.36 & 4,377 & 0.37 & 14,473 & $\begin{array}{l}\text { Collins et } \\
\text { al. (2013) }\end{array}$ \\
\hline A. ostoyae & $\mathrm{C} 18 / 9$ & Europe & 60.10 & 106 & & 22,705 & $\begin{array}{l}\text { Sipos et al. } \\
(2017)\end{array}$ \\
\hline A. ostoyae & $28-4$ & $\begin{array}{l}\text { North } \\
\text { America }\end{array}$ & 58.01 & 229 & 0.72 & 20,811 & $\begin{array}{l}\text { Sipos et al. } \\
(2017)\end{array}$ \\
\hline A. fuscipes & $\begin{array}{l}\text { CMW } \\
2740\end{array}$ & Africa & 53.00 & & 0.01 & 14,515 & $\begin{array}{l}\text { Wingfield } \\
\text { et al. } \\
(2016)\end{array}$ \\
\hline
\end{tabular}

1) $\mathrm{N} 50$ is the shortest sequence length at $50 \%$ of the genome assembly.

${ }^{2)}$ Summary statistics for the $A$. mellea genome reported in Collins et al. (2013) are different from those reported in the JGI genome portal (i.e. total length: $79.55 \mathrm{Mbp}$; number of scaffolds: 29,300; N50: 0.02). 


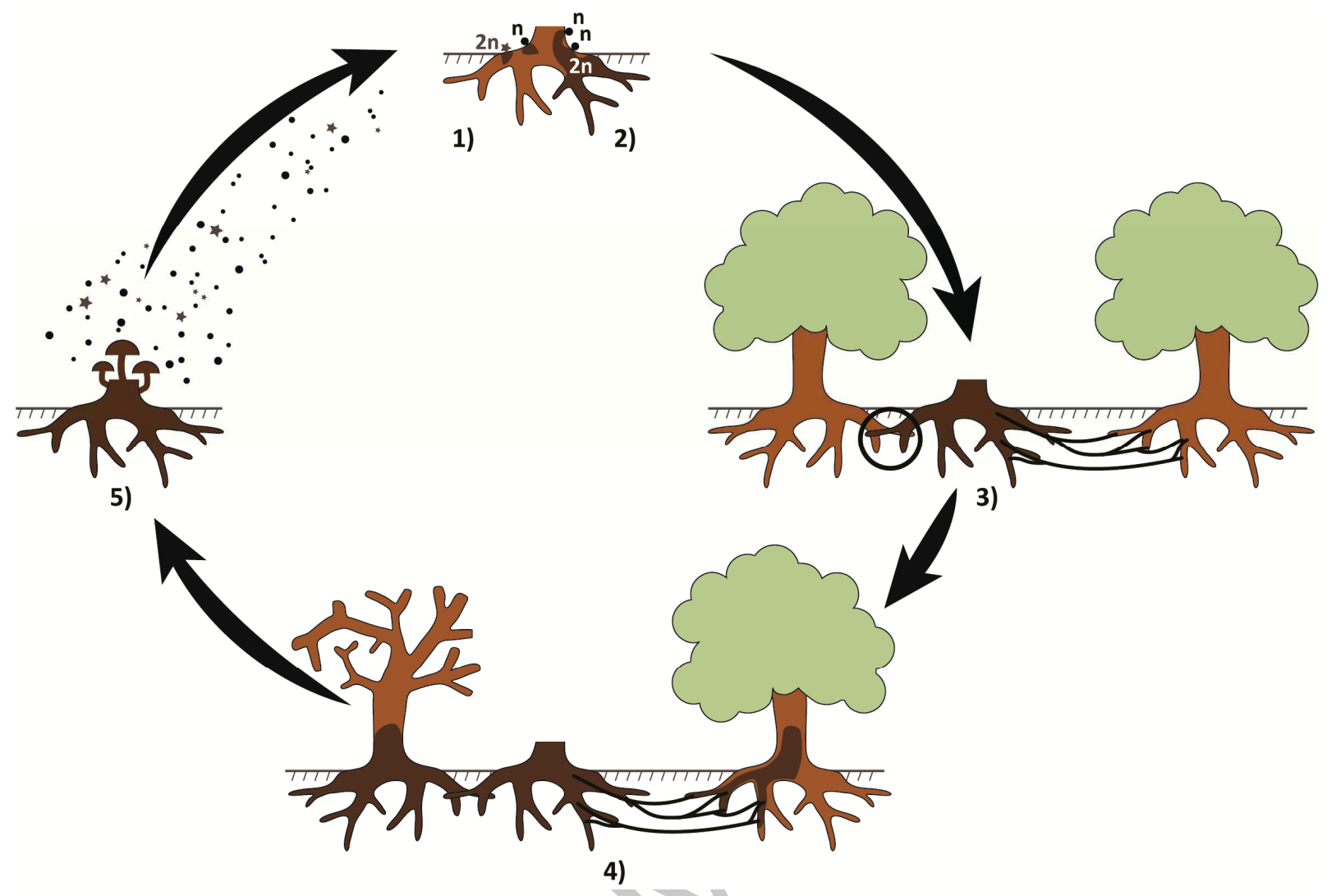

Figure 1. Schematic representation of the life cycle of Armillaria species. (1) Basidiospores germinate on woody substrate (e.g. wood fragments, possibly stumps) originating a haploid (n) mycelium (heterothallic species) or a diploid (2n) mycelium (homothallic species); (2) In heterothallic species, after mating between two compatible haploid mycelia, a diploid mycelium is formed. In both heterothallic and homothallic species, the diploid mycelium colonizes the woody substrate; (3) Healthy trees are infected either by root contacts with infected woody substrates or by soil rhizomorphs growing out from infected woody substrate; (4) Armillaria invades the root system and lower stem of the infected trees, killing the cambium or/and causing heart rot; (5) Fruiting bodies develop on dead/moribund woody substrate and release basidiospores into the environment. 


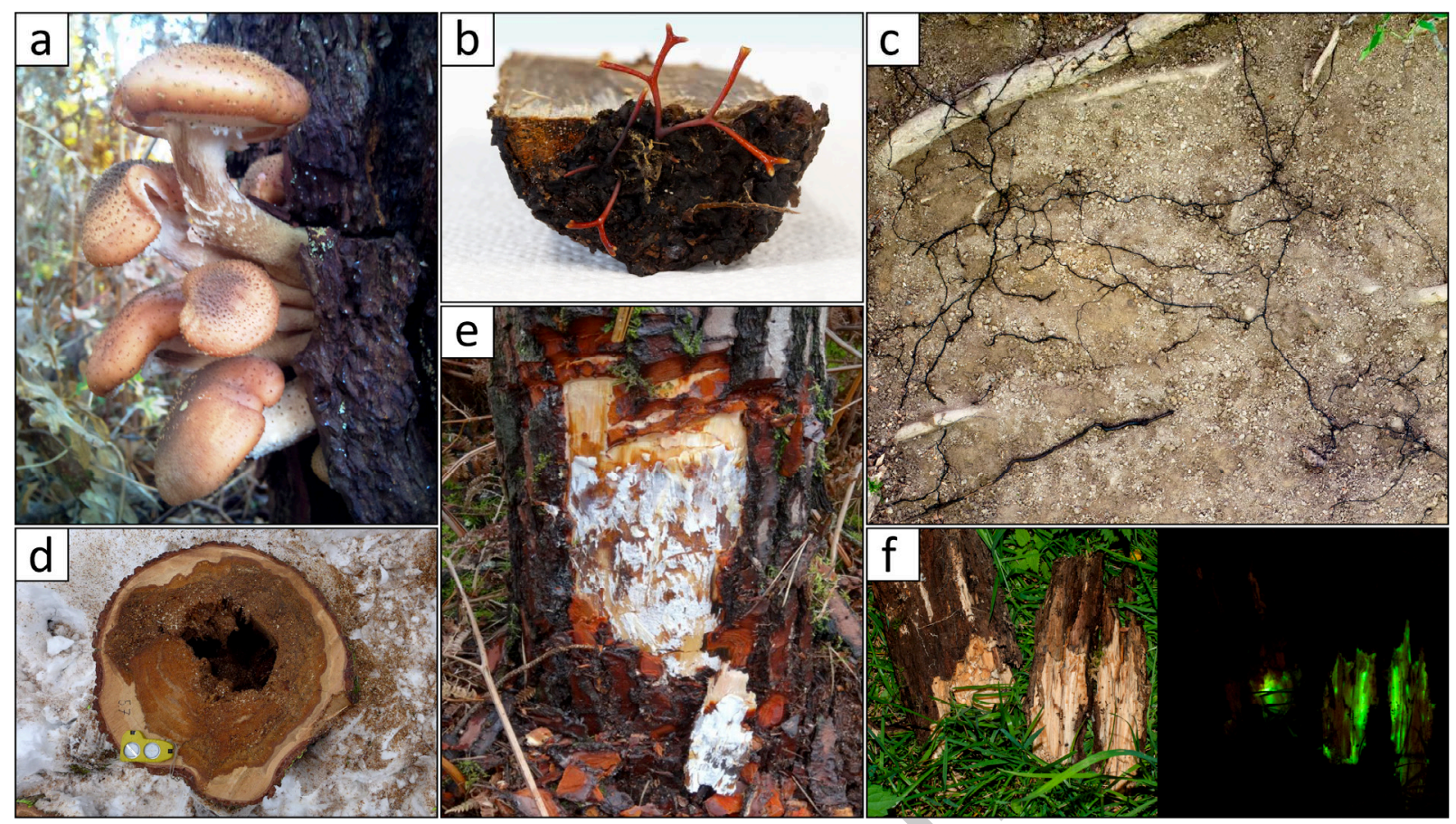

Figure 2. Main signs of the presence of Armillaria species. (a) Fruiting bodies of A. ostoyae on

the trunk of a dead maritime pine (Pinus pinaster); (b) Rhizomorphs growing out of a wood segment colonized by A. borealis; (c) Network of rhizomorphs of Armillaria spp. in the soil. (d) Heart rot caused by A. cepistipes on Norway spruce (Picea abies); (e) Mycelial fans of A. ostoyae developing in the cambial area of an infected maritime pine; (f) Armillaria spp. colonized wood fragments showing typical bioluminescence. Photo credits: (a) F. Labbé; (b) and (e) R. Heinzelmann; (c) and (f), H. Baggenstos/A. Rudolf; (d) Phytopathology, WSL. 


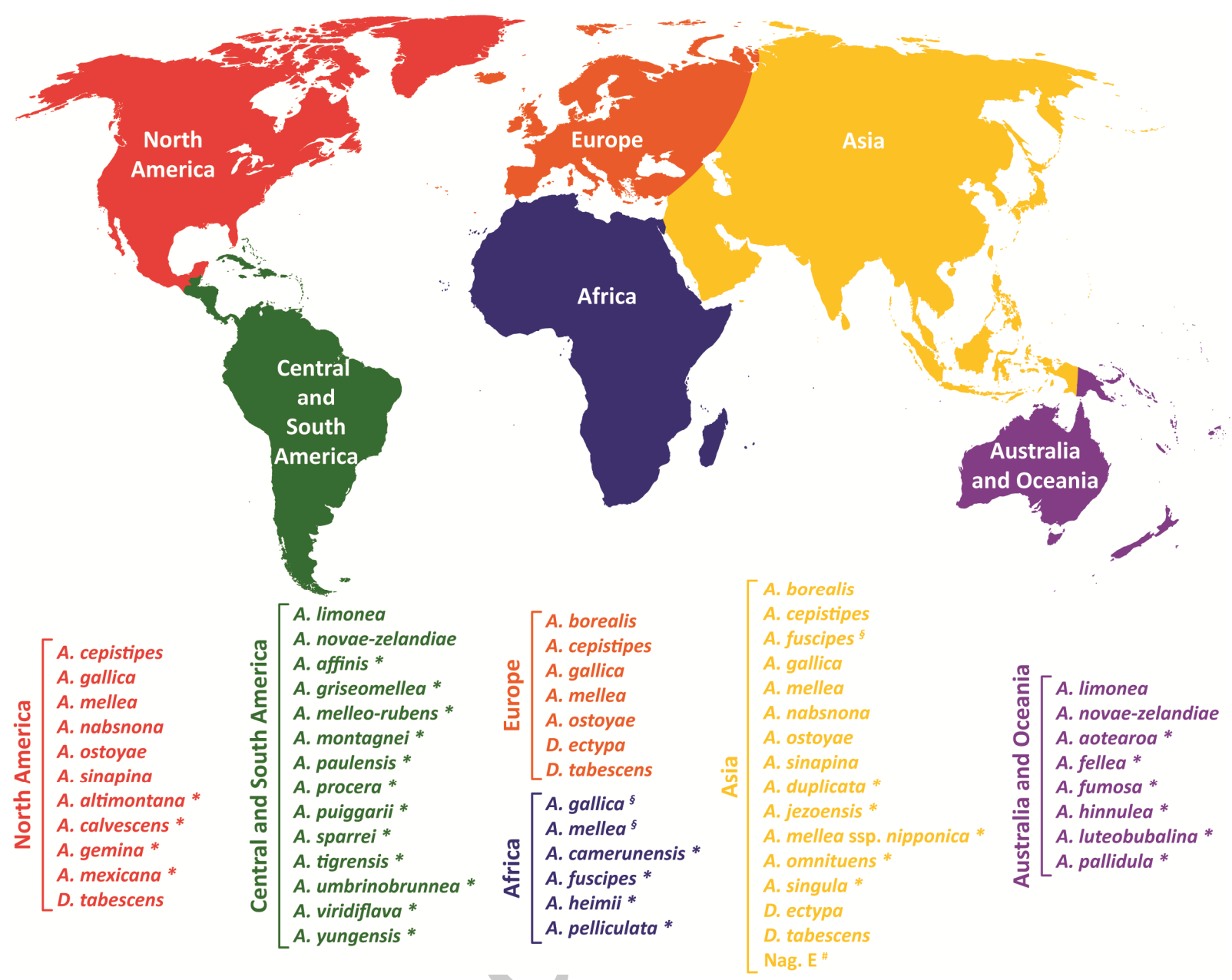

Figure 3. Geographical distribution of the currently known Armillaria s.s. and Desarmillaria species (Korhonen 1978; Anderson and Ullrich 1979; Roll-Hansen 1985; Anderson 1986; Motta and Korhonen 1986; Watling et al. 1991; Guillaumin et al. 1993; Termorshuizen and Arnolds 1994; Cha and Igarashi 1995; Volk and Burdsall 1995; Abomo-Ndongo and Guillaumin 1997; Ota et al. 1998; Coetzee et al. 2001b; Coetzee et al. 2003; Qin et al. 2007; Lima et al. 2008; Pildain et al. 2010; Brazee et al. 2012b; Hood and Ramsfield 2016; Elías-Román et al. 2018). * indicates species that is only reported in the specific geographic area. ${ }^{\S}$ indicates species putatively introduced into the specific geographic area. ${ }^{\#}$ indicates biological species awaiting formal description. 